\title{
Fire emission heights in the climate system - Part 2: Impact on transport, black carbon concentrations and radiation
}

\author{
A. Veira ${ }^{1,2}$, S. Kloster ${ }^{1}$, N. A. J. Schutgens ${ }^{3}$, and J. W. Kaiser ${ }^{4}$ \\ ${ }^{1}$ Max Planck Institute for Meteorology, Hamburg, Germany \\ ${ }^{2}$ International Max Planck Research School on Earth System Modelling, Hamburg, Germany \\ ${ }^{3}$ Department of Physics, University of Oxford, Oxford, UK \\ ${ }^{4}$ Max Planck Institute for Chemistry, Mainz, Germany \\ Correspondence to: A. Veira (andreas.veira@mpimet.mpg.de)
}

Received: 10 December 2014 - Published in Atmos. Chem. Phys. Discuss.: 06 March 2015

Revised: 03 June 2015 - Accepted: 03 June 2015 - Published: 01 July 2015

\begin{abstract}
Wildfires represent a major source for aerosols impacting atmospheric radiation, atmospheric chemistry and cloud micro-physical properties. Previous case studies indicated that the height of the aerosol-radiation interaction may crucially affect atmospheric radiation, but the sensitivity to emission heights has been examined with only a few models and is still uncertain. In this study we use the general circulation model ECHAM6 extended by the aerosol module HAM2 to investigate the impact of wildfire emission heights on atmospheric long-range transport, black carbon (BC) concentrations and atmospheric radiation. We simulate the wildfire aerosol release using either various versions of a semiempirical plume height parametrization or prescribed standard emission heights in ECHAM6-HAM2. Extreme scenarios of near-surface or free-tropospheric-only injections provide lower and upper constraints on the emission height climate impact. We find relative changes in mean global atmospheric $\mathrm{BC}$ burden of up to $7.9 \pm 4.4 \%$ caused by average changes in emission heights of $1.5-3.5 \mathrm{~km}$. Regionally, changes in BC burden exceed $30-40 \%$ in the major biomass burning regions. The model evaluation of aerosol optical thickness (AOT) against Moderate Resolution Imaging Spectroradiometer (MODIS), AErosol RObotic NETwork (AERONET) and Cloud-Aerosol Lidar with Orthogonal Polarization (CALIOP) observations indicates that the implementation of a plume height parametrization slightly reduces the ECHAM6-HAM2 biases regionally, but on the global scale these improvements in model performance are small. For prescribed emission release at the surface, wildfire emissions entail a total sky top-of-atmosphere (TOA) radiative forcing (RF) of $-0.16 \pm 0.06 \mathrm{~W} \mathrm{~m}^{-2}$. The appli-
\end{abstract}

cation of a plume height parametrization which agrees reasonably well with observations introduces a slightly stronger negative TOA RF of $-0.20 \pm 0.07 \mathrm{~W} \mathrm{~m}^{-2}$. The standard ECHAM6-HAM2 model in which $25 \%$ of the wildfire emissions are injected into the free troposphere (FT) and $75 \%$ into the planetary boundary layer (PBL), leads to a TOA RF of $-0.24 \pm 0.06 \mathrm{~W} \mathrm{~m}^{-2}$. Overall, we conclude that simple plume height parametrizations provide sufficient representations of emission heights for global climate modeling. Significant improvements in aerosol wildfire modeling likely depend on better emission inventories and aerosol process modeling rather than on improved emission height parametrizations.

\section{Introduction}

Within the last 2 decades, comprehensive observational and modeling studies have investigated and quantified the importance of biomass burning aerosols for direct, semi-direct and indirect radiative effects and aerosol-cloud precipitation interaction (Haywood and Boucher, 2000; Lohmann and Feichter, 2005; Bowman et al., 2009). The global black carbon $(\mathrm{BC})$ emissions from vegetation fires are estimated to range between 1.7 and $3.0 \mathrm{Tg} \mathrm{BC} \mathrm{yr}^{-1}$, which is equivalent to roughly $30 \%$ of the global total $\mathrm{BC}$ emissions including fossil fuels (e.g., Andreae and Merlet, 2001; Reid et al., 2005; Bond et al., 2013). Regardless of the considerable progress that has been made concerning our understanding of the direct, semi-direct and indirect aerosol effects, the ability of recent global climate models to reproduce observations and 
climate-related changes in carbonaceous aerosol concentrations is very limited (Dentener et al., 2006; Kinne et al., 2006; Koch et al., 2009). Important sources of bias could be identified to arise from large uncertainties in the fire emission inventories, improper transport mechanisms and removal processes (Bond et al., 2013; Schwarz et al., 2013). Long-range transport and removal processes of biomass burning aerosols in turn depend to some extent on the emission heights. Samset et al. (2013) published a comprehensive comparison of 12 global aerosol models in the framework of the Aerosol Comparisons between Observations and Models (AEROCOM) project. The authors found that most of the AEROCOM models attribute more than $40 \%$ of the $\mathrm{BC}$ radiative forcing (RF) to altitudes higher than $5 \mathrm{~km}$, although only $24 \%$ of the BC mass is found above $5 \mathrm{~km}$. Thus, the vertical emission distribution at the time of the wildfire emission release can be identified as a key parameter for the overall radiative impact of wildfire emissions.

In former studies the terms "fire emission heights", "injection heights", "plume-top heights" and "plume heights" have been equally used to describe top heights of wildfire emission injections and the subsequent vertical distributions. In this study, we propose the term "plume height" to describe the maximum altitude above the surface at which emissions are released (e.g., prescribed, or calculated by a plume height parametrization). The term "emission height" implies the complete vertical emission distribution from the surface to the top of the smoke plume.

Although advanced emission height models are available for implementation in global circulation models (e.g., Luderer et al., 2006; Freitas et al., 2007; Rio et al., 2010), there is an ongoing discussion about which degree of complexity in emission height parametrization is required for global Climate Modeling. Due to a lack of observational plume height data sets of global coverage, our knowledge regarding appropriate emission height parametrizations for specific global modeling applications is largely based on short-term or regional studies. By application of inverse Lagrangian modeling techniques, the early studies of Liousse et al. (1996), Wotawa and Trainer (2000) and Spichtinger et al. (2001) found the best matches of modeled aerosol transport to observations for emission distributions between 0 and 2, 0.5 and 3 , and 3 and $5 \mathrm{~km}$ for $\mathrm{BC}, \mathrm{CO}$ and $\mathrm{NO}_{x}$ concentrations, respectively. Chen et al. (2009) showed that emission heights are substantially more important for BC than for trace gases, which questions the general transferability of the results from trace gas studies to BC. Other studies provided good agreement of model simulations with observations for an emission release between the surface and the planetary boundary layer (PBL) height as well as a fixed height of $1.2 \mathrm{~km}$ (Wang et al., 2006; Matichuk et al., 2007). While Jian and Fu (2014) found a large sensitivity of $\mathrm{BC}$ concentrations on the emission heights, Colarco (2004) demonstrated that the differences between a near-surface emission release and a release between 2 and $6 \mathrm{~km}$ are small for convective atmospheric conditions. Chen et al. (2009) used the GEOS-CHEM model with Global Fire Emission Data Base 2 (GFED2) emissions to simulate the smoke transport from North American forest fires. The authors found the best overall model performance for a scenario of $40 \%$ emissions injected into PBL and $60 \%$ emissions injected into the free troposphere (FT). For a study by Stein et al. (2009), in one case PBL injections performed best, whereas in another case plume heights up to $3 \mathrm{~km}$ were necessary to reproduce observations. Gonzi et al. (2015) applied a modified version of the 1-D plume model by Freitas et al. (2007), Moderate Resolution Imaging Spectroradiometer (MODIS) fire radiative power (FRP) and fire size to simulate global CO concentrations in GEOS-Chem for the year 2006. The authors compared modeling results to MOPITT (Measurement of Pollution in the Troposphere) satellite data, but it turned out that the particular emission height impact on the overall bias was not quantifiable. Overall, modeling as well as observational studies (e.g., Diner et al., 2008; Val Martin et al., 2010; Ichoku et al., 2012) indicate that wildfire plume heights are highly variable on the global scale. While Freitas et al. (2007), Rio et al. (2010) and others demonstrated a reasonable performance for their specific plume height parametrizations in particular case studies; other authors including Val Martin et al. (2012) and Goodrick et al. (2012) presented results that showed a poor to moderate performance of all these models on the global scale.

In summary, our knowledge about both, an appropriate implementation of emission heights in global climate models as well as the impact of the emission heights on aerosol longrange transport, atmospheric radiation and other climate variables is very limited. In the first part of this two-paper series (Veira et al., 2015), we presented globally simulated plume height patterns. Through a comparison of simulated plume heights to observations from the Multiangle Imaging Spectroradiometer (MISR) Plume Height Project (MPHP) data set, we evaluated the performance of different plume height implementations. The best agreement of model results to observations was found for a modified version of the Sofiev et al. (2012) plume height parametrization (modeled global mean plume heights $1411 \pm 646 \mathrm{~m}$, observed mean global plume heights $1382 \pm 702 \mathrm{~m}$ ). Only $5.2 \pm 1.0 \%$ of all daytime plumes were injecting emissions into the FT. On average, plume heights simulated by the semi-empirical parametrization are 1.1-2.0 km lower than prescribed standard plume heights in ECHAM6-HAM2. Based on the simulations introduced in Veira et al. (2015) and the additional extreme scenarios (pure surface and free-tropospheric injections) presented in this paper, we analyze atmospheric BC concentrations, $\mathrm{BC}$ deposition rates and atmospheric radiation for all simulations to address the following research questions:

- To what extent do wildfire emission heights impact atmospheric aerosol concentrations and aerosol-radiation interaction? 
- How important is the vertical distribution of the released emissions?

- Does the diurnal cycle of fire intensity and emission release enhance, dampen or change the sign of the averaged climate response?

- How might a future increase in fire intensity and emissions influence plume heights and radiation?

- What degree of complexity in plume height parametrization is required to capture the emission height impact on aerosol long-range transport and atmospheric radiation in global climate models?

A comprehensive comparison of modeled aerosol optical thickness (AOT; also referred to as aerosol optical depth, AOD) to observational data sets from the Maritime Aerosol Network (MAN), the AErosol RObotic NETwork (AERONET), the MODIS and the Cloud-Aerosol Lidar with Orthogonal Polarization (CALIOP) gives us an independent constraint on an adequate choice of plume height parametrizations for climate modeling applications.

The next section introduces our model setup, the different plume height implementations and the observational data sets used for model evaluation. In the "Comparison of model results to observations" section, the impact of the wildfire emission heights on $\mathrm{BC}$ concentrations, deposition rates and radiation is analyzed. Furthermore, we present regional time series and statistical analysis on the model performance. The conclusions section summarizes our results and provides suggestions for future implementations of plume height parametrizations in climate and Earth system models based on our findings.

\section{Methodology: simulations setup}

\subsection{ECHAM6-HAM2}

The aerosol-climate modeling system ECHAM6-HAM2 is an extension of ECHAM6, the atmospheric component of the Max Planck Institute Earth system model (MPI-ESM) (Stevens et al., 2013). ECHAM6-HAM2 predicts the evolution of micro-physically interacting aerosol populations, their size distribution and composition (Stier et al., 2005; Zhang et al., 2012). For all our simulations, we use model version ECHAM6.1.0-HAM2.2. We apply a spatial grid of approximately $1.875^{\circ} \times 1.875^{\circ}$ (T63) and a temporal resolution of $600 \mathrm{~s}$. The 47 vertical layers range from the surface to $0.01 \mathrm{hPa}$. To allow for appropriate comparisons of the wildfire RF, the model is nudged against observational data every $6 \mathrm{~h}$ by relaxation of the prognostic variables to ERAInterim reanalysis fields (Dee et al., 2011). The aerosol module HAM2 employs a superposition of seven lognormal distributions which describe the nucleation, Aitken, accumulation and coarse modes. Besides dust, sea salt and sulfur emis- sions from natural and anthropogenic sources, the model also simulates the emission and transport of carbonaceous matter from anthropogenic sources and wildfires.

Wildfire emissions are represented by three species in the ECHAM6-HAM2 model: BC, organic carbon (OC) and sulfur dioxide $\left(\mathrm{SO}_{2}\right)$. For details on the implementation of sedimentation, wet and dry deposition, thermodynamics and aerosol micro-physics parametrization, see Stier et al. (2005). A detailed assessment of the processes which drive the evolution of aerosol mass and number concentrations is described in Schutgens and Stier (2014). Calculations of aerosol optical properties are based on Mie theory for 24 solar spectral bands and provide single scattering albedo, extinction cross section and asymmetry factors. These parameters in turn serve as input for radiation calculations by the ECHAM6 radiation scheme (Giorgetta et al., 2013; Stevens et al., 2013). Aerosol-cloud interactions are represented by a two-moment cloud micro-physics scheme that is coupled to the aerosol micro-physics (Lohmann et al., 2007). Overall, we carry out nine ECHAM6-HAM2 simulations with different emission height implementations for 8 years (2004-2011) which will be described in the next two sections. The year 2004 is used for the spin-up of the model and therefore excluded from our analysis.

\subsection{Emission data sets}

In the standard release of ECHAM6-HAM2, AEROCOM phase 2 wildfire emissions (Dentener et al., 2006) are implemented. These emissions are based on GFEDv2 data (Werf et al., 2006) multi-year monthly means of the years 19972008. GFEDv2 emissions are derived from burnt area observations and do not provide any information on wildfire intensity. As fire intensity is a key input parameter required for plume height parametrizations, the AEROCOM emission data set within the standard ECHAM6-HAM2 model does not represent an appropriate framework to study wildfire emission heights. In contrast to GFED, the Global Fire Assimilation System (GFASv1.1) (Kaiser et al., 2012) uses FRP retrieved from MODIS satellite observations to estimate fire emissions from the year 2000 to present. GFAS applies land-cover-specific emission factors to calculate combustion rates and fills observational gaps by use of a Kalman filter. With consistent aerosol emission and fire intensity information, GFASv1.1 provides an appropriate input data set for our simulations.

Kaiser et al. (2012) found that GFAS emissions implemented in the global circulation model ECMWF are only able to reproduce AOT observations in a reasonable way, if global GFAS wildfire emissions are multiplied by a global factor of 3.4. This zero-order approximation also provided reasonable global modeling results in studies by Huijnen et al. (2012) and von Hardenberg et al. (2012) using the global MACC (Monitoring Atmospheric Composition and Climate) atmospheric composition forecasting system as 
Table 1. Setup of ECHAM6-HAM2 simulations for 2005-2011 based on various plume height parametrizations. All simulations are nudged towards observations every $6 \mathrm{~h}$. In addition to the listed simulations, a NO-WILDFIRES scenario represents a simulation without any wildfire emissions. See text for a more detailed description of the emission height implementations and emission inventories.

\begin{tabular}{|c|c|c|c|c|}
\hline Simulation name & $\begin{array}{l}\text { Plume height } \\
\text { parametrization }\end{array}$ & $\begin{array}{l}\text { Diurnal cycle } \\
\text { of FRP }\end{array}$ & $\begin{array}{l}\text { Emission } \\
\text { inventory }\end{array}$ & Emission distribution \\
\hline HAM2.2-GFAS & PBL Height +2 model layers & NO & GFAS & $25 \%$ into FT, $75 \%$ into PBL \\
\hline SOFIEV-ORIGINAL & SOFIEV (Original) & NO & GFAS & $\begin{array}{l}\text { constant mass mixing ratio top- } \\
\text { bottom }\end{array}$ \\
\hline SOFIEV-DCYCLE & SOFIEV (Original) & YES & GFAS & $\begin{array}{l}\text { constant mass mixing ratio top- } \\
\text { bottom }\end{array}$ \\
\hline SOFIEV-MODIFIED & SOFIEV (Modified) & YES & GFAS & $\begin{array}{l}\text { constant mass mixing ratio top- } \\
\text { bottom }\end{array}$ \\
\hline SOFIEV-TOP-INJECTION & SOFIEV (Original) & YES & GFAS & $\begin{array}{l}50 \% \text { into top layer, } 50 \% \text { top- } \\
\text { bottom }\end{array}$ \\
\hline SURFACE & $\begin{array}{l}2 \text { lowest model layers }(30-150 \mathrm{~m} \\
\text { above surface) }\end{array}$ & NO & GFAS & $\begin{array}{l}100 \% \text { into the lowest and sec- } \\
\text { ond lowest layer }\end{array}$ \\
\hline FT & PBL Height to Tropopause & NO & GFAS & $\begin{array}{l}100 \% \text { into } \mathrm{FT} \text {, constant mass } \\
\text { mixing ratio }\end{array}$ \\
\hline $\begin{array}{l}\text { SOFIEV-2X-EMISSIONS- } \\
\text { FRP }\end{array}$ & SOFIEV (Original, $2 \times$ FRP) & NO & GFAS & $\begin{array}{l}\text { constant mass mixing ratio top- } \\
\text { bottom }\end{array}$ \\
\hline HAM2.2-AEROCOM & PBL Height +2 model layers & NO & AEROCOM-II & $25 \%$ into FT, $75 \%$ into PBL \\
\hline
\end{tabular}

well as ECHAM5-HAM1. Basically, the underestimation of AOT in GFAS and other bottom-up inventories could have various reasons including an underestimation of emission fluxes (e.g., due to underestimation of wildfire emission factors or burned area as well as FRP) as well as shortcomings in the representation of aerosol micro-physics in the model (impacting aging and removal rates). It would be highly desirable to investigate the reasons for the required factor of 3.4 in more detail in a future study.

We apply the GFASv1.1 emission data set for eight out of nine simulations, but we also run one simulation with the standard AEROCOM wildfire emissions to provide a reference which is comparable to other ECHAM6-HAM2 studies. As the global annual emission fluxes of GFAS and AEROCOM show mean differences of less than $9.2 \%$ for BC and $4.4 \%$ for OC, we decided to apply the 3.4 factor not only to GFAS but also to AEROCOM wildfire emissions. For both, AEROCOM as well as GFAS simulations, wildfire emissions are represented by the emission species $\mathrm{BC}, \mathrm{OC}$ and $\mathrm{SO}_{2}$.

In addition, we run one "NO-WILDFIRES" scenario for which wildfire emissions are completely switched off to calculate the overall wildfire emission impact on radiation.

\subsection{Emission height parametrizations}

Table 1 provides a summary of all plume height parametrizations used in this study. Based on the large range of emission height implementations in the literature, we apply first the most extreme and unrealistic scenarios for our sensitivity study: on the one hand the experiment "SURFACE" simulates a wildfire emission release into the lowest and second lowest model layer (approximately 30-150 m above the surface). Thus, this simulation provides the lower limit of the emission height radiative impact due to fast removal of the aerosols close to the surface. Wildfire emissions in simulation SURFACE were chosen to be distributed into the two lowest model layers instead of the surface layer only, because in preliminary test runs prior to this study, very intense wildfire emission releases concentrated at one specific model layer resulted in model instabilities, presumably due to radiative imbalance. On the other hand a simulation of purely free-tropospheric emission release (FT) serves as an unrealistic upper constraint of the emission height climate impact.

In the standard version of ECHAM6-HAM2.2, plume heights for all wildfires are prescribed as the PBL height plus two model layers:

$H_{\mathrm{p}}=$ PBL height +2 model layers.

If the PBL height exceeds $4 \mathrm{~km}, H_{\mathrm{p}}$ is set to a PBL height. We use this implementation as a reference simulation "HAM2.2GFAS". For a more appropriate representation of wildfire emission heights in ECHAM6-HAM2, we implemented the semi-empirical plume height parametrization introduced by Sofiev et al. (2012), henceforth also referred to as "Sofiev Parametrization" (SP). In contrast to the standard emission heights in ECHAM6-HAM2, the SP takes into account the total FRP of a fire $P_{\mathrm{f}}$ as well as atmospheric stability (BruntVäisälä frequency of the atmosphere $N$ ) and PBL height $H_{\mathrm{PBL}}$ to predict fire emission heights:

$H_{\mathrm{p}}=\alpha H_{\mathrm{PBL}}+\beta\left(\frac{P_{\mathrm{f}}}{P_{\mathrm{f} 0}}\right)^{\gamma} \exp \left(-\delta N^{2} / N_{0}^{2}\right)$.

For more details on the SP, a description of the normalizing constants $N_{0}$ and $P_{\mathrm{f} 0}$ as well as the tuning parameters 
$\alpha, \beta, \gamma$ and $\delta$ and all modifications we applied (e.g., introduction of a diurnal cycle in FRP), see Veira et al. (2015) and Sofiev et al. (2012). Overall we carry out five simulations with different implementations of the SP: the original and most simple one-step model as described in Sofiev et al. (2012) called "SOFIEV-ORIGINAL", one simulation with additional application of a diurnal cycle in fire emissions and FRP called "SOFIEV-DCYCLE" and one simulation which applies a diurnal cycle as well as a tuning of high plumes "SOFIEV-MODIFIED". Simulation SOFIEVMODIFIED represents the plume height parametrization which provides the best agreement to global plume height observations (see Veira et al., 2015). A hypothetical future scenario with a doubling in FRP and emissions, "SOFIEV2X-EMISSIONS-FRP", enables a comparison of the impact of changes in emission fluxes and emission heights. We assume the $\mathrm{BC} / \mathrm{OC} / \mathrm{SO}_{2}$ emission ratios for simulation SOFIEV-2X-EMISSIONS-FRP to be constant and apply $\mathrm{BC} / \mathrm{OC} / \mathrm{SO}_{2}$ ratios provided by GFASv1.1. The last simulation "SOFIEV-TOP-INJECTION" is run to test the influence of the vertical emission distribution.

\subsection{Vertical distribution of wildfire emissions}

Besides the plume heights which describe the maximum level of emission injection above the surface, one has to make assumptions on the vertical distribution of the emissions from the surface to the plume height. For all SOFIEV simulations, we distribute emissions from the surface to the top of the plume with a constant mass mixing ratio. Simulation FT also applies a constant mass mixing ratio from the PBL height to the first level below the tropopause. In the simulation SURFACE, all wildfire emissions are injected into the first two model layers approximately $30-150 \mathrm{~m}$ above the surface. HAM2.2-AEROCOM and HAM2.2-GFAS use the vertical emission distribution prescribed in the standard HAM2.2 model with a fraction of $25 \%$ of the emissions to be injected into the free troposphere (in the two levels just above the PBL). The remaining $75 \%$ of the emissions are distributed from the surface to the PBL height with constant mass mixing ratio.

Vertical emission distributions with constant mass mixing ratios have been used in most former global aerosol modeling studies even in case of more advanced plume models, e.g., Freitas et al. (2007). Our knowledge about the global variability of vertical emission distributions is even more limited than our knowledge about the plume heights. However, Luderer et al. (2006) and Fromm et al. (2010) showed in modeling, as well as observational case studies, that rare but extraordinarily high injections might emit a large fraction of the emissions into the upper part of the plumes. To account for this, we perform one sensitivity study, in which we emit $50 \%$ of the total emissions into the uppermost layer of the plume and we distribute the remaining $50 \%$ uniformly

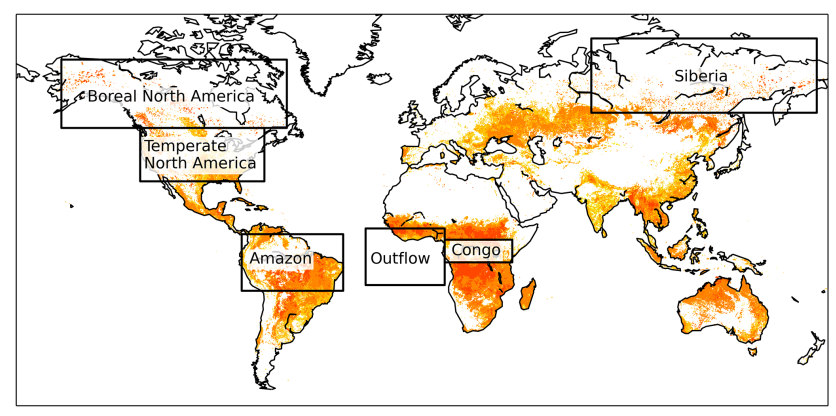

Figure 1. Region specification of major biomass burning areas for comparison of modeled AOT to observations. Color shading represents mean annual assimilated FRP values of GFASv1.1 for 20052011. Yellow colors indicate low FRP values, dark red colors indicate high FRP values.

(constant mass mixing ratio) into the model layers below (SOFIEV-TOP-INJECTION).

\subsection{Observational data sets for model evaluation}

For evaluation of the ECHAM6-HAM2 model performance, vertically resolved and integrated AOT values are compared to observations from AERONET, MODIS, MAN and CALIOP. The AERONET program (Holben et al., 1998) is a ground network of sun photometers that provides longterm continuous AOT measurements based on the attenuation of direct solar radiation. These AOT measurements are estimated to have errors of $\approx 0.015$ (Eck et al., 1999; Schmid et al., 1999) and are considered some of the most accurate aerosol observations we have. In this study, we use AERONET AOT which was averaged over $6 \mathrm{~h}$, every $6 \mathrm{~h}$.

The MAN is an integrated component of AERONET and includes data from ship cruises since the end of 2004 (Smirnov et al., 2011). It is based on hand held Microtops II sun photometers with five spectral channels ranging from 320 to $1020 \mathrm{~nm}$ providing data for spectral AOT. The MAN data set has limited spatial and temporal coverage due to the limited number of ship cruises which collected data (about 1700 individual days of measurements between November 2006 and March 2010).

In addition to AERONET data, spectral radiance measurements from the two MODIS sensors aboard the Aqua and Terra satellites are used to monitor AOT with a wide spatial coverage. MODIS AOT values are calculated by retrieval algorithms based on lookup tables for different particles which depend on scattering geometries (Tanre et al., 1997). Error estimations of MODIS AOT retrievals have been investigated by comparison with ground-based AERONET (e.g., Remer et al., 2005; Bréon et al., 2011) and MAN observations (e.g., Adames et al., 2011; Smirnov et al., 2011; Schutgens et al., 2013). Here we use the Naval Research Laboratory (NRL) L3 (Hyer et al., 2011; Shi et al., 2011) data that are derived from MODIS L2 observations through additional quality checks 
Table 2. Global mean values (2005-2011) describing aerosol atmospheric aerosol transport and radiation for various parametrizations of plume heights in ECHAM6-HAM2.2. The NO-WILDFIRES simulation serves as reference for calculation of total sky top-of-atmosphere (TOA) radiative forcing (RF) shown in columns "Surface RF" and "TOA RF". Simulation HAM2.2-AEROCOM is based on AEROCOM emissions, for all other simulations we use GFASv1.1 emissions. The asterisk $\left(^{*}\right)$ in the last column indicates that plume height values represent 10th to 90th percentiles. For a detailed plume height and emission inventory setup of all scenarios, see Table 1. Uncertainties represent 1 SD (standard deviation) of monthly means for 2005-2011.

\begin{tabular}{|c|c|c|c|c|c|c|c|c|c|}
\hline Simulation name & $\begin{array}{r}\text { BC burden } \\
{[\mathrm{Tg}]}\end{array}$ & $\begin{array}{r}\text { OC burden } \\
{[\mathrm{Tg}]}\end{array}$ & $\begin{array}{r}\text { BC wet } \\
\text { deposition } \\
{\left[\mathrm{Tg} \mathrm{yr}^{-1}\right]}\end{array}$ & $\begin{array}{r}\text { BC dry } \\
\text { deposition } \\
{\left[\mathrm{Tg} \mathrm{yr}^{-1}\right]}\end{array}$ & $\begin{array}{r}\mathrm{BC} \\
\text { sedimentation } \\
{\left[\mathrm{Tg} \mathrm{yr}^{-1}\right]}\end{array}$ & $\begin{array}{r}\text { BC lifetime } \\
\text { [days] }\end{array}$ & $\begin{array}{r}\text { Surface RF } \\
{\left[\mathrm{W} \mathrm{m}^{-2}\right]}\end{array}$ & $\begin{array}{l}\text { TOA RF } \\
{\left[\mathrm{W} \mathrm{m}^{-2}\right]}\end{array}$ & $\begin{array}{r}\text { Plume } \\
\text { heights* } \\
{[\mathrm{km}]}\end{array}$ \\
\hline HAM2.2-GFAS & $0.34 \pm 0.02$ & $3.03 \pm 0.20$ & $13.60 \pm 0.69$ & $1.06 \pm 0.04$ & $0.032 \pm 0.002$ & $8.50 \pm 0.23$ & $-1.75 \pm 0.18$ & $-0.24 \pm 0.05$ & $1.8-3.9$ \\
\hline SOFIEV-ORIGINAL & $0.33 \pm 0.02$ & $2.87 \pm 0.18$ & $13.55 \pm 0.68$ & $1.13 \pm 0.05$ & $0.033 \pm 0.002$ & $8.08 \pm 0.19$ & $-1.62 \pm 0.17$ & $-0.20 \pm 0.05$ & $0.8-1.9$ \\
\hline SOFIEV-DCYCLE & $0.33 \pm 0.02$ & $2.89 \pm 0.18$ & $13.56 \pm 0.69$ & $1.11 \pm 0.04$ & $0.033 \pm 0.002$ & $8.15 \pm 0.19$ & $-1.63 \pm 0.17$ & $-0.20 \pm 0.06$ & $1.0-2.2$ \\
\hline SOFIEV-MODIFIED & $0.33 \pm 0.02$ & $2.90 \pm 0.18$ & $13.56 \pm 0.69$ & $1.11 \pm 0.04$ & $0.033 \pm 0.002$ & $8.17 \pm 0.20$ & $-1.63 \pm 0.16$ & $-0.20 \pm 0.07$ & $1.0-2.3$ \\
\hline SOFIEV-TOP_INJ & $0.33 \pm 0.02$ & $2.95 \pm 0.19$ & $13.59 \pm 0.69$ & $1.07 \pm 0.04$ & $0.032 \pm 0.002$ & $8.28 \pm 0.21$ & $-1.67 \pm 0.16$ & $-0.21 \pm 0.6$ & $1.0-2.2$ \\
\hline SURFACE & & $2.76 \pm 0.16$ & $13.33 \pm 0.66$ & $1.35 \pm 0.07$ & & & & $-0.16 \pm 0.06$ & $0.1-0.2$ \\
\hline FT & $1.26 \pm 0.11$ & $13.01 \pm 1.15$ & $13.60 \pm 0.55$ & $0.89 \pm 0.02$ & $0.035 \pm 0.001$ & $31.58 \pm 2.34$ & $-7.37 \pm 1.16$ & $+0.66 \pm 0.24$ & $10.9-15.8$ \\
\hline SOFIEV-2X-EMISSIONS-FRP & $0.57 \pm 0.04$ & $5.40 \pm 0.41$ & $21.46 \pm 1.38$ & $1.46 \pm 0.07$ & $0.058 \pm 0.006$ & $9.08 \pm 0.29$ & $-3.28 \pm 0.34$ & $-0.36 \pm 0.11$ & $0.9-2.2$ \\
\hline HAM2.2-AEROCOM & $0.36 \pm 0.01$ & $3.17 \pm 0.08$ & $14.44 \pm 0.02$ & $1.07 \pm 0.02$ & $0.035 \pm 0.001$ & $8.50 \pm 0.02$ & $-1.82 \pm 0.09$ & $-0.25 \pm 0.06$ & $1.8-3.9$ \\
\hline
\end{tabular}

and empirical correction formulae. Both, the Aqua as well as the Terra NRL L3 data, are $1^{\circ}$ by $1^{\circ}$ aggregates, available every $6 \mathrm{~h}$. MODIS observations do provide a far wider spatial coverage than AERONET, but uncertainties are significantly larger. For the quantitative analysis of the plume height parametrization, we restrict our considerations to six major biomass burning regions: boreal North America, temperate North America, Siberia, the Amazon area and neighboring regions, Congo and the African outflow to the tropical Atlantic (Fig. 1).

Vertically resolved information of AOT is provided by the CALIOP on board the CALIPSO satellite which was launched in June 2006 to acquire global aerosol profile data between $82^{\circ} \mathrm{N}$ and $82^{\circ} \mathrm{S}$ (Winker et al., 2010). CALIOP provides backscatter profiles at a vertical resolution of $30 \mathrm{~m}$ (below $8.2 \mathrm{~km}$ ) as well as $60 \mathrm{~m}$ (between 8.2 and $20.2 \mathrm{~km}$ ). Vertical aerosol extinction profiles are calculated at 1064 and $532 \mathrm{~nm}$ (Winker et al., 2013). CALIOP vertical AOT profiles have a good global coverage, but the uncertainties in individual AOT profiles are known to be large due to uncertainties in lidar ratios (e.g., Campbell et al., 2013; Winker et al., 2013). There is a tendency of CALIOP to underestimate low AOT values and the lowest $1.4 \mathrm{~km}$ are not reasonably captured. The gridded CALIOP level 3 data have been shown to provide more accurate AOT values than level 2 data because of an improved retrieval algorithm for the lowest $1.4 \mathrm{~km}$ (Kacenelenbogen et al., 2011; Redemann et al., 2012). Therefore, in this study, we apply multi-annual monthly means of level 3 data for 2006-2011 and restrict our analysis to relative vertical AOT profiles. For our analysis, we use only complete CALIOP vertical profiles without missing individual layers. Absolute AOT values are vertically averaged to 0.5 or $1.0 \mathrm{~km}$ layers for our comparison to ECHHAM6-HAM2 model simulations.

In contrast to the spatially and temporally collocated MODIS, AERONET and MAN data of 6 hourly resolution, which we use for the comparison of total AOT to ECHAM6HAM2 simulations, CALIOP level 3 data are only available in monthly temporal and $2^{\circ} \times 5^{\circ}$ (latitude $\times$ longitude) horizontal resolution. Therefore, the introduced errors in the CALIOP model-observations comparison are a priori larger for the CALIOP data then for MODIS, AERONET and MAN data. On the other hand CALIOP is the only data set which provides vertically resolved AOT profiles of global coverage.

\section{The impact of changes in fire emission heights on BC burdens, concentrations and deposition rates}

Differences in emission height parametrizations can be expected to cause differences in the vertical and horizontal transport of the wildfire emissions. To quantify these changes in global aerosol transport, we assess regional and global changes in BC burdens, vertical concentration profiles and deposition rates. We analyze 7 years of model simulations (2005-2011) for the nine emission height scenarios provided in Table 1.

\subsection{BC burdens}

Global mean values of the atmospheric BC and OC aerosol burdens for all individual experiments are presented in Table 2. As the patterns of changes in $\mathrm{OC}$ concentrations and deposition rates are very similar to the changes in $\mathrm{BC}$, we limit our detailed analysis to $\mathrm{BC}$. Changes in $\mathrm{SO}_{2}$ are not discussed in this paper as $\mathrm{SO}_{2}$ emissions from wildfires contribute only about $5 \%$ to the overall $\mathrm{SO}_{2}$ emissions. Table 2 also reports the range of plume heights simulated in the individual experiments. Global plume height patterns are discussed in detail in Veira et al. (2015). All global mean values provided in Table 2 are complemented by more detailed and region-specific discussions within the next three sections. Note that all uncertainty estimates in Table 2 (except 
for the plume heights) represent 1 standard deviation (SD) of monthly global means for 2005-2011.

Figure 2 illustrates the global relative changes in BC burden for the individual experiments compared to the standard ECHAM6-HAM2 setup (simulation HAM2.2-GFAS). For the various implementations of the Sofiev plume height parametrization (SOFIEV-ORIGINAL, SOFIEV-DCYCLE, SOFIEV-MODIFIED, SOFIEV-TOP-INJECTION; see Fig. 2a-d), the global patterns of changes in BC burden are very similar in the tropics and subtropics. While an increase in $\mathrm{BC}$ burden is observable close to the source regions, the implementation of the plume height parametrization introduces a reduction in $\mathrm{BC}$ burden far from the source regions. The simulated changes in $\mathrm{BC}$ burden can be attributed to a decreased aerosol long-range transport. The application of a diurnal cycle (SOFIEV-DCYCLE) which increases the height of daytime plumes, and a more realistic representation of deep emission injections (SOFIEV-MODIFIED), introduce only marginal changes in $\mathrm{BC}$ burden. In the TOP-INJECTION scenario, which injects $50 \%$ of the emissions into the highest emission layer, the sign of the relative changes in $\mathrm{BC}$ burden compared to simulation HAM2.2-GFAS changes in boreal regions. The higher burdens can be attributed to the importance of strong boreal forest fire events which emit significant fractions of the emissions into the FT. Although the majority of emission injections in the SOFIEV simulations are injecting below the HAM2.2-GFAS emission heights, a small fraction of strong emission events simulated by the Sofiev parametrizations exceeds the HAM2.2-GFAS maximum emission heights of PBL height + two model layers (see Veira et al., 2015). The comparison of simulations SOFIEV-ORIGINAL, SOFIEVDCYCLE and SOFIEV-MODIFIED shows that the changes in $\mathrm{BC}$ burden introduced by the application of a diurnal cycle and more realistic deep plumes are rather small on the global scale. Simulation SURFACE, the extreme scenario of pure near-surface emission injections, provides an estimate of the lower limit of the global BC burden (Fig. 2e). For the near-surface emission injections, residence times and therefore also BC burdens are increased in the vicinity of the sources, while long-range transport is generally reduced. The negative relative changes in $\mathrm{BC}$ burden are more pronounced in the Southern Hemisphere and range from 10 to $25 \%$.

Global mean relative changes in BC burden introduced by the replacement of prescribed emission heights in HAM2.2 by the implementation of various versions of the Sofiev plume height parametrization range between -2.6 and $-4.8 \%$ for BC and -2.7 and $-5.5 \%$ for OC. For the SURFACE scenario, global BC and OC burdens are reduced by $-7.9 \%$ and $-8.9 \%$, respectively. These changes are remarkably small due to the fact that median global plume heights between these simulations range from about $0.15 \mathrm{~km}$ for the SURFACE simulation to $2.7 \mathrm{~km}$ for the HAM2.2-GFAS prescribed plume heights (see Veira et al., 2015). Consequently, these results indicate that the vertical mixing in ECHAM6HAM2 acts very efficiently in the lower troposphere.

The extreme and unrealistic scenario of purely freetropospheric injections shows an increase in $\mathrm{BC}$ burden over Antarctica by more than 20 times (see Fig. 2f). BC burdens in simulation FT are dominated by long-range transport rather than the emission sources. Because of the proportionately higher fraction of wildfire emission to the overall $\mathrm{BC}$ burden in the Southern Hemisphere, the relative changes in $\mathrm{BC}$ burden in these regions are more sensitive to plume height changes. The scenario of a doubling in FRP and fire emissions (Fig. 2g) entails an increase in atmospheric BC burden which largely exceeds the changes of the other simulations except the unrealistic FT scenario. In scenario SOFIEV2X-EMISSIONS-FRP, which assumes a doubling in FRP and wildfire emissions corresponding to an overall increase in total BC emissions by $56.7 \%$, the global BC burden is non-linearly enhanced by $38.7 \%$ compared to simulation SOFIEV-DCYCLE. This dampening of the increase in atmospheric $\mathrm{BC}$ concentrations for increased emissions can be attributed to the interaction of multiple aerosol microphysical and atmospheric effects. These include but are not limited to non-linear particle formation, coagulation and deposition, micro-physical cloud processes and atmospheric feedback via changes in vertical temperature profiles due to changes in aerosol concentrations and radiation. However, in the framework of this study, it is impossible to disentangle the contribution of particular processes to the overall non-linear source-receptor relationship. A comparable magnitude in damping of the atmospheric response to an increased emission release has been found by Zhang et al. (2014) within a WRF-CHEM modeling study. Note that the differences in plume heights for a doubling in FRP and emissions do not exceed $100-500 \mathrm{~m}$ on average for $95 \%$ of all plumes (see Veira et al., 2015).

Although the global mean differences in emission fluxes between AEROCOM and GFAS are only $9.2 \%$, the regional differences are considerably larger. For boreal regions (60$80^{\circ} \mathrm{N}$ ), GFAS BC emission fluxes are roughly 2 times the AEROCOM emission fluxes. In the temperate regions (20$60^{\circ} \mathrm{N}$ and $20-60^{\circ} \mathrm{S}$ ) GFAS is about $18.8 \%$ higher than AEROCOM. In the tropical source regions $\left(20^{\circ} \mathrm{S}\right.$ to $\left.20^{\circ} \mathrm{N}\right)$, which dominate the global burden, AEROCOM BC emission fluxes exceed the GFAS emission fluxes by $17.9 \%$. Figure $2 \mathrm{~h}$ shows large regional differences in atmospheric burden between the HAM2.2-GFAS and the HAM2.2-AEROCOM simulations applying the same plume height parametrization. These differences in BC burdens largely reflect the spatial differences in the emission inventories. Nevertheless, the mean total global BC burdens of HAM2.2-AEROCOM $(0.36 \pm 0.01 \mathrm{Tg})$ and HAM2.2-GFAS $(0.34 \pm 0.02 \mathrm{Tg})$ are very similar as a result of similar mean global emission fluxes.

The global mean BC lifetime of realistic plume height implementations ranges between $8.1 \pm 0.1$ days for the 


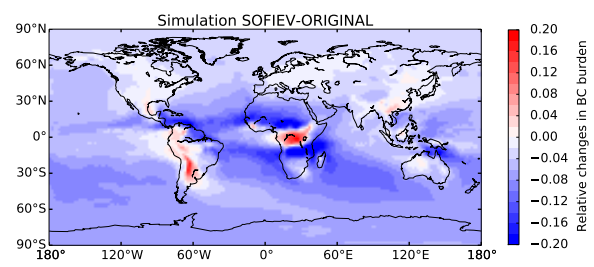

(a)

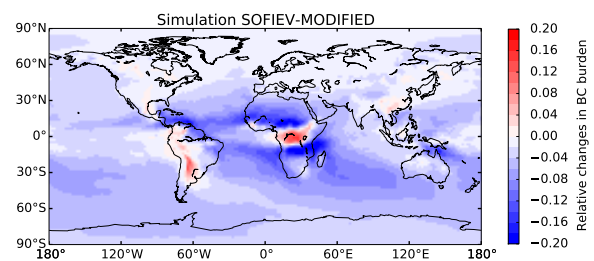

(c)

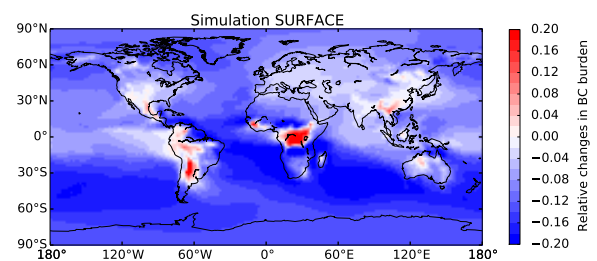

(e)

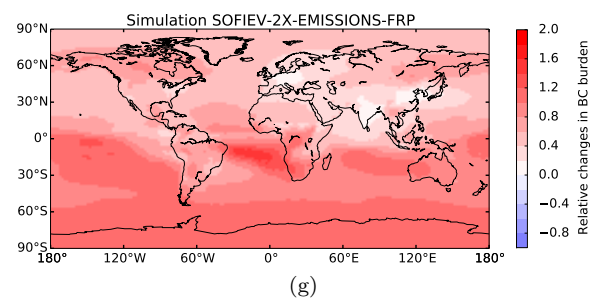

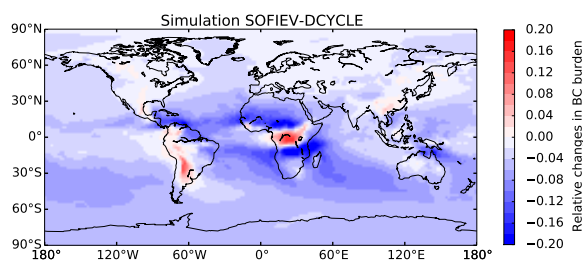

(b)

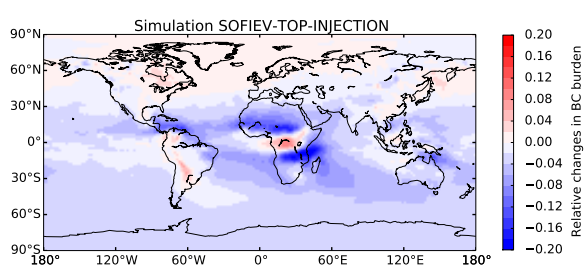

(d)

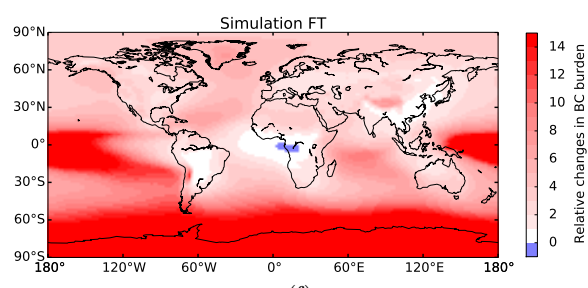

(f)

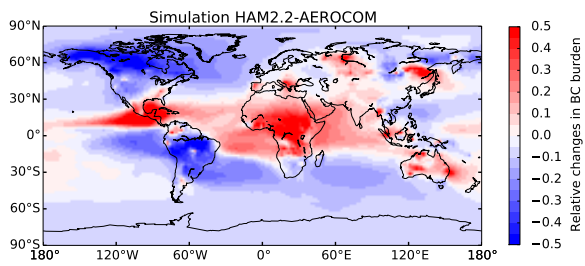

(h)

Figure 2. Mean relative changes in $\mathrm{BC}$ burden introduced by various implementations of fire emission heights. All relative changes refer to the standard implementation of prescribed emission heights combined with GFASv1.1 emissions (simulation HAM2.2-GFAS). Simulations SOFIEV-ORIGINAL (a), SOFIEV-DCYCLE (b), SOFIEV-MODIFIED (c) and SOFIEV-TOP-INJECTION (d) show different versions of the Sofiev plume height parametrization. Simulation SURFACE (e) represents near-surface emissions, simulation FT (f) is based on purely freetropospheric emissions. SOFIEV-2X-EMISSIONS-FRP (g) assumes a doubling in emissions and FRP. HAM2.2-AEROCOM (h) illustrates the influence of changes in the emission inventory. For a description of settings for simulations (a) to (h), see Table 1.

SOFIEV-ORIGINAL simulation and $8.5 \pm 0.2$ days for the prescribed standard emission heights in HAM2.2-GFAS (see Table 2). For similar daytime emission heights, a doubling in wildfire emissions (simulation SOFIEV-DCYCLE vs. SOFIEV-2X-EMISSIONS-FRP) enhances the mean BC lifetime by $22.3 \mathrm{~h}$. An increase in plume heights by $1.7-$ $3.7 \mathrm{~km}$ for simulation HAM2.2-GFAS compared to simulation SURFACE introduces an increase in BC lifetime by about $16.3 \mathrm{~h}$. Due to the GFAS emission flux factor of 3.4 applied in this study, these lifetimes are substantially larger than mean BC lifetimes of 5.9 days in ECHAM6-HAM2 shown by Zhang et al. (2012). However, the lifetimes in our study are within the range of the AEROCOM models for which mean lifetimes of 7.1 days with a $33 \%$ SD were found (Textor et al., 2006).

\subsection{Vertical BC concentration profiles}

Figure 3 presents vertical cross sections of relative changes in BC concentrations as zonal means for 2005-2011. Compared to the HAM2.2-GFAS simulation with a prescribed emission injection of $25 \%$ into the FT, the on average much lower Sofiev emission heights lead to increased BC concentrations near the surface and decreased $\mathrm{BC}$ concentrations in the FT. Differences in BC concentrations between the various versions of the Sofiev plume height parametrization are largely smaller than 5\% (Fig. 3a-d). However, for the SOFIEVTOP-INJECTION scenario, the near-surface concentrations 


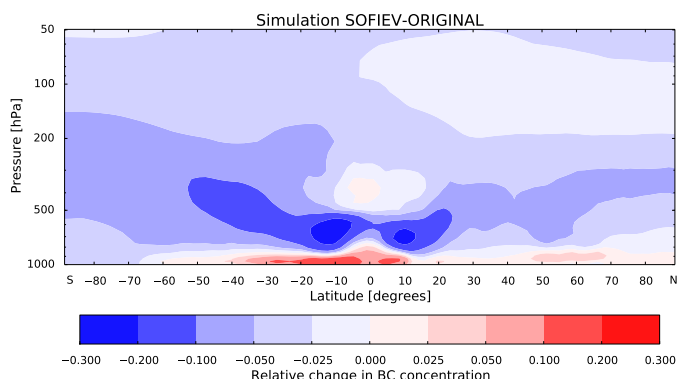

(a)

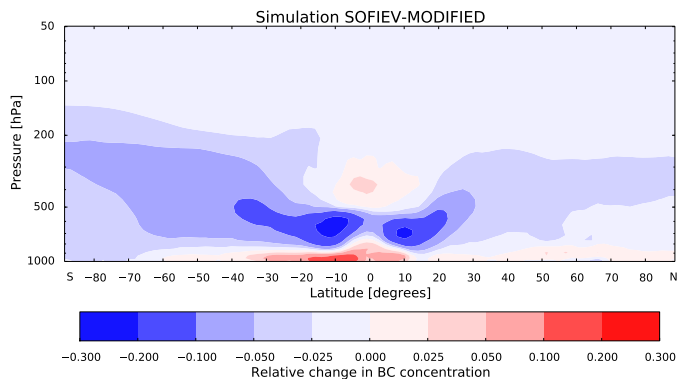

(c)

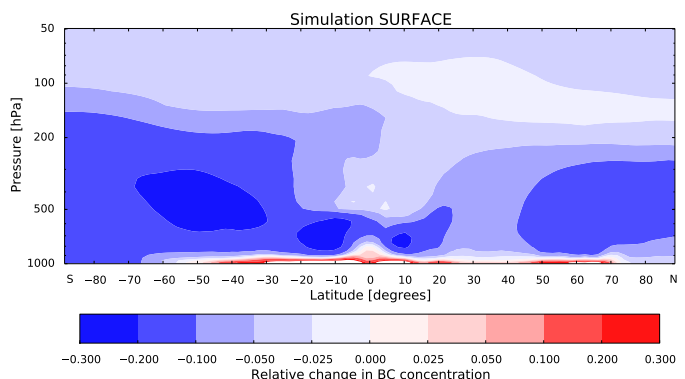

(e)

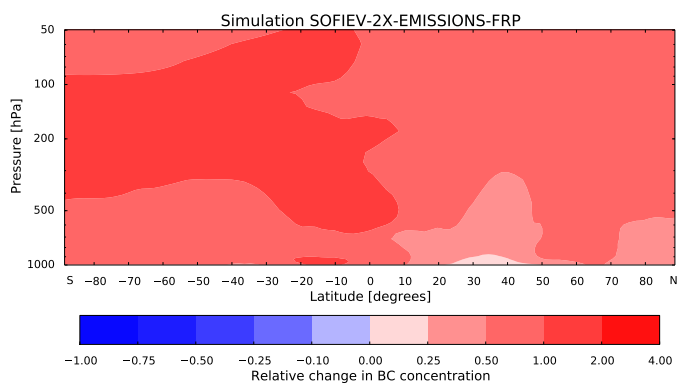

(g)

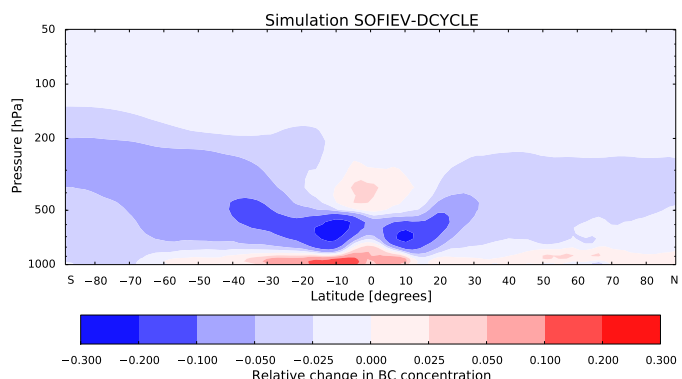

(b)

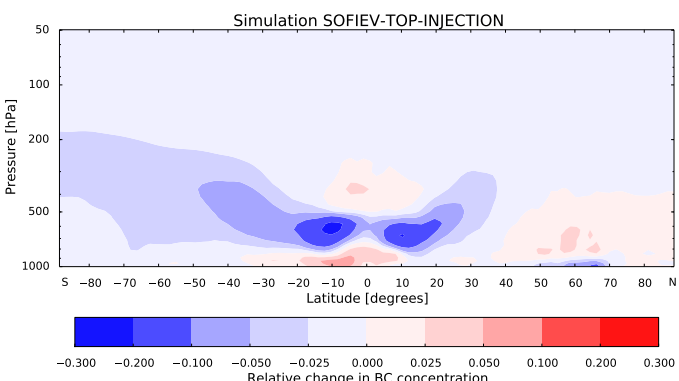

(d)

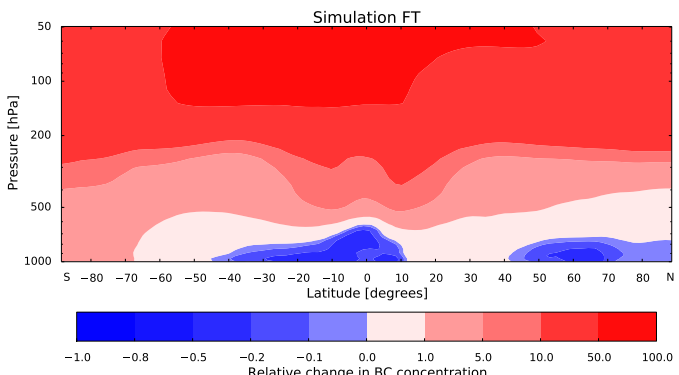

(f)

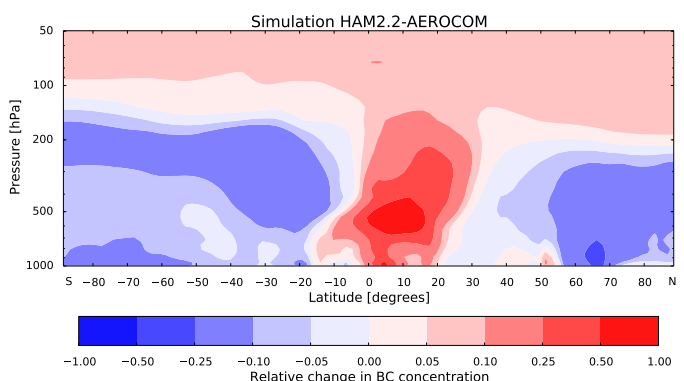

(h)

Figure 3. Mean relative changes in zonal mean BC concentrations for 2005-2011. All relative changes refer to the standard implementation of prescribed emission heights combined with GFASv1.1 emissions (simulation HAM2.2-GFAS). A more detailed description of the simulation setups is provided in Table 1 .

are substantially lower than for the other SOFIEV simulations (see Fig. 3d). In the tropics, a slight increase in BC concentrations is observable between 500 and $300 \mathrm{hPa}$ for all SOFIEV simulations. This enhancement in tropical freetropospheric BC concentrations cannot be directly attributed to differences in emission heights which are smaller in all SOFIEV simulations compared to the HAM2.2-GFAS standard emission heights. Moreover, Fig. 2a-d show a substantial increase in BC burden in equatorial Africa for the Sofiev simulations. As the regions of increased burden coincide with 


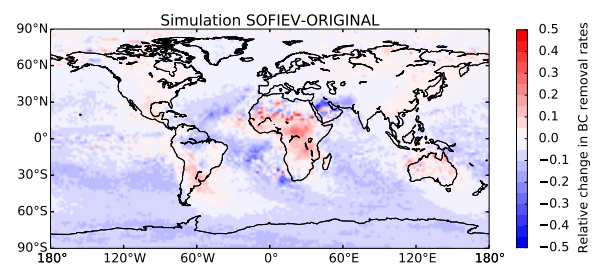

(a)

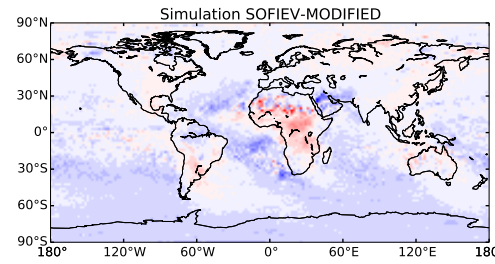

(c)

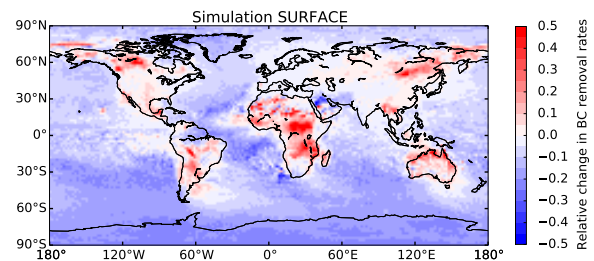

(e)

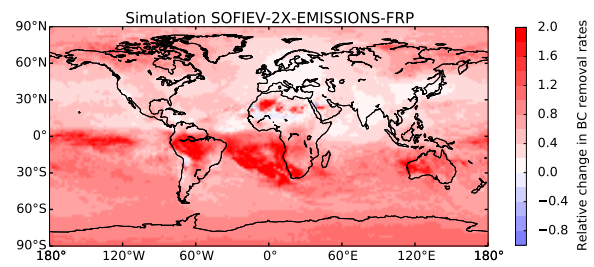

(g)

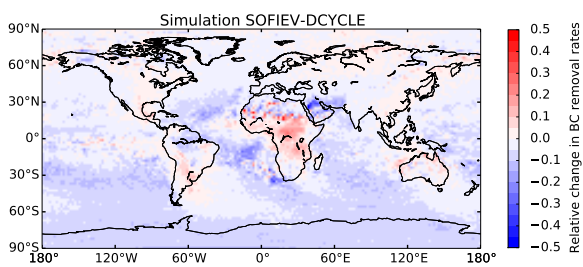

(b)

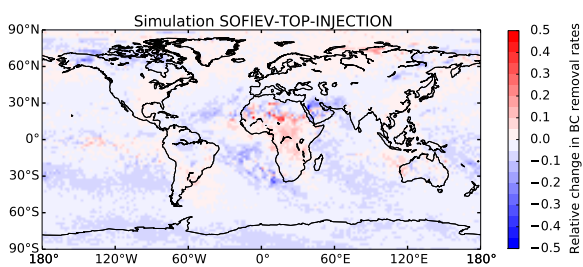

(d)

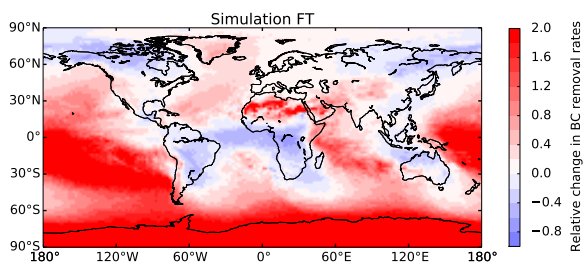

(f)

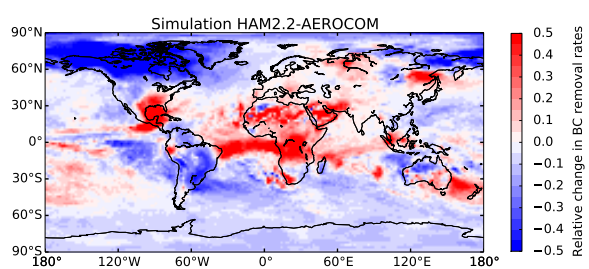

(h)

Figure 4. Simulated mean total deposition rates from 2005 to 2011. All relative changes refer to the standard implementation of prescribed emission heights combined with GFASv1.1 emissions (simulation HAM2.2-GFAS). A more detailed description of the simulation setups is provided in Table 1 .

the strongest tropical convective zones, we assume that deep convection is the major process which determines the freetropospheric $\mathrm{BC}$ concentrations, not the emission heights.

For simulation SURFACE, a decrease in mean BC concentrations up to $25 \%$ in the Southern Hemispheric FT is found, but the sensitivity of stratospheric BC concentrations to emission heights is very limited (relative changes $<5 \%$ ). The other extreme scenario (simulation FT) shows an upper tropospheric and lower stratospheric increase in BC concentrations by a factor of $10-100$ which substantially impacts the radiative transfer (see Sect. 5). For the SOFIEV2X-EMISSIONS-FRP scenario, the largest relative increase in BC concentrations is observable in the Southern Hemispheric upper troposphere and lower stratosphere. Simulation HAM2.2-AEROCOM (see Fig. 3h) reflects the enhanced tropical wildfire emission fluxes in the AEROCOM emission data set compared to GFAS. As a result of the tropical convective transport, BC concentrations in the lower stratosphere are increased by $5-20 \%$ all over the globe in the HAM2.2-AEROCOM simulation. On the other hand, the extratropical tropospheric BC concentrations are decreased by $5-25 \%$.

Overall Fig. 3 demonstrates that upper tropospheric and lower stratospheric BC concentrations are not very sensitive to the emission heights if realistic emission height scenarios are applied.

\subsection{Total deposition rates}

Wet deposition rates, dry deposition rates and sedimentation rates for $\mathrm{BC}$ are provided in Table 2. A potential climate impact of $\mathrm{BC}$ emissions is related to the deposition of $\mathrm{BC}$ on snow and ice which substantially reduces the surface albedo (e.g., Dumont et al., 2014). In this context, the question arises how strongly deposition rates in the Arctic and Antarctic 


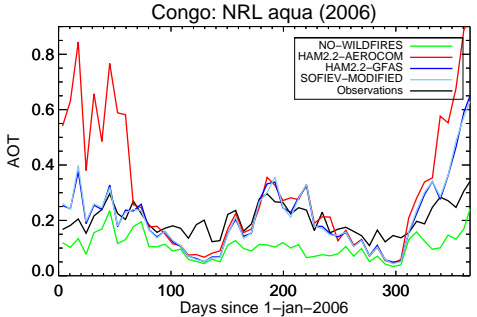

(a)

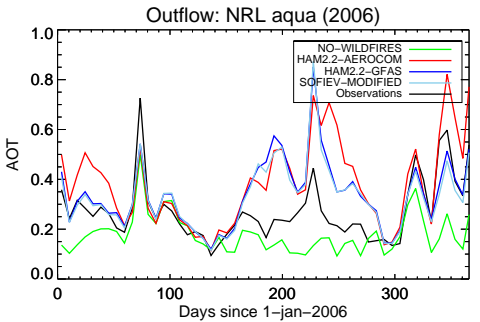

(d)

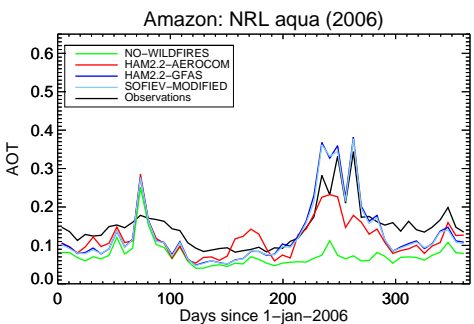

(g)

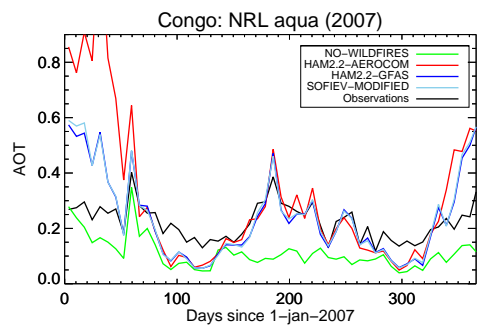

(b)

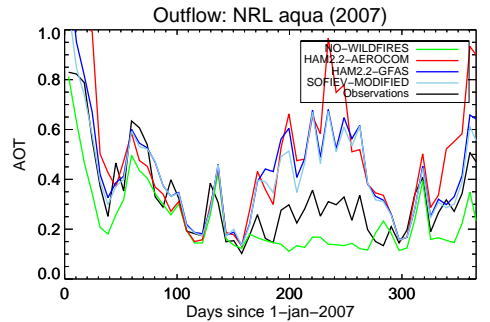

(e)

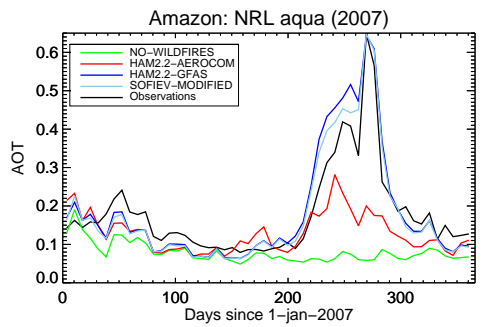

(h)

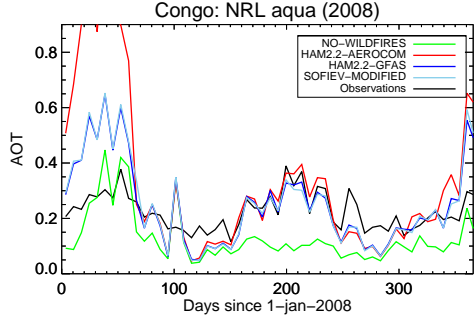

(c)

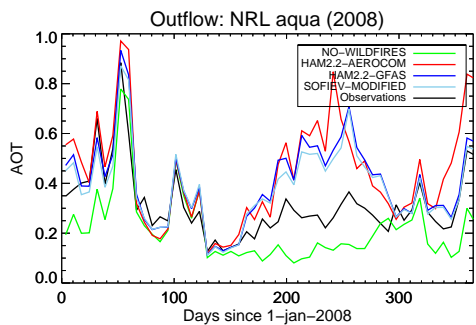

(f)

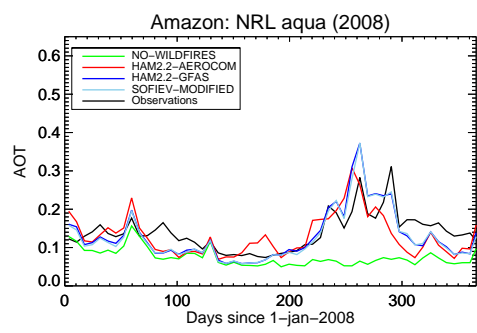

(i)

Figure 5. Temporal evolution of regional AOT for standard HAM2.2 plume heights based on GFAS emissions (HAM2.2-GFAS) as well as AEROCOM emissions (HAM2.2-AEROCOM) and a modified plume height parametrization of Sofiev et al. (2012) including a diurnal cycle of fire emissions and fire intensity (simulation SOFIEV-MODIFIED). The NO-WILDFIRES scenario is shown to distinguish wildfire-related biases from others. Observations are MODIS Aqua satellite measurements of AOT. All model data were collocated with the observations prior to averaging.

depend on emission heights. Figure 4 presents the relative changes in total deposition rates for our various plume height implementations. Simulation SOFIEV-ORIGINAL reflects an increase in deposition rates in the vicinity of the major source regions due to lower emission heights. In contrast, the reduced remote deposition rates can be attributed to a decreased atmospheric long-range transport. Changes introduced by a consideration of the diurnal cycle in fire emissions (SOFIEV-DCYCLE) and a more accurate representation of high plumes (SOFIEV-MODIFIED) only marginally influence the deposition rates on the global scale. Over Antarctica, total deposition rates are decreased by 20-25\% for the SURFACE emission release compared to the HAM2.2 standard implementation. Over the glaciated areas of Greenland and the northern polar ice sheet, the reduction ranges between 10 and $20 \%$. However, although these changes are substantial, the known model biases in aerosol long-range transport to the Arctic, which have been found for ECHAM5-
HAM1 by Bourgeois and Bey (2011) and von Hardenberg et al. (2012), may still persist. A global doubling of emissions and fire intensity results in a southern hemispheric increase in regional deposition rates of 60-140\% (Fig. 4g). In the Northern Hemisphere this increase is significantly smaller, because the $\mathrm{BC}$ release in mid-latitudes is largely dominated by anthropogenic emissions, not by wildfires.

\section{Comparison of model results to observations}

Our temporal analysis for six biomass burning regions (see Fig. 1) for 2006-2008 is restricted to four simulations: a zero wildfire emissions scenario (NO-WILDFIRES), the HAM2.2-AEROCOM and the HAM2.2-GFAS simulations, both applying HAM2.2 emissions heights and the SOFIEVMODIFIED simulation which is most appropriately representing the global spectrum of plume heights. For the 


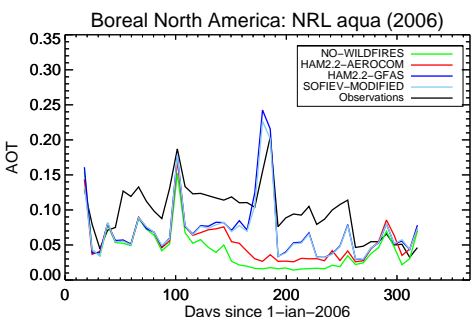

(a)

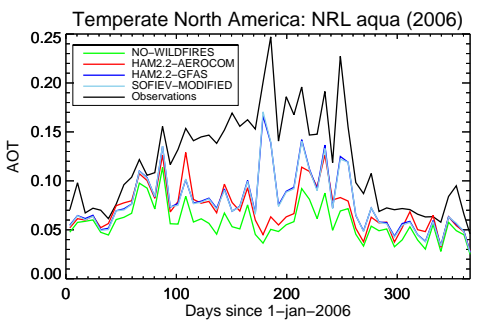

(d)

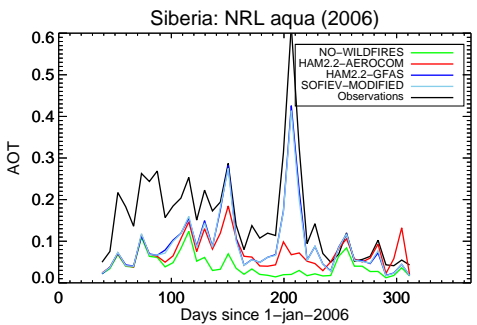

(g)

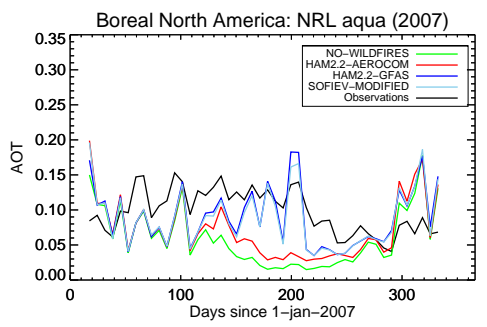

(b)

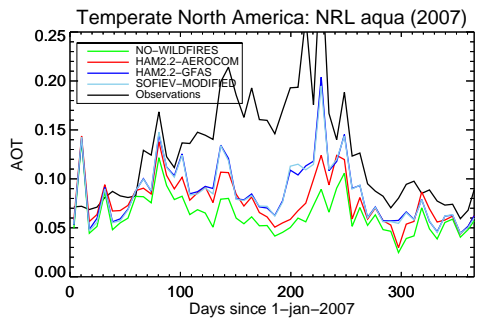

(e)

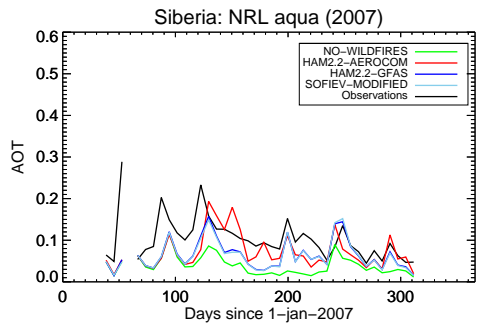

(h)

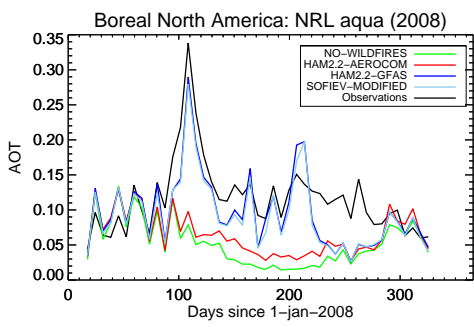

(c)

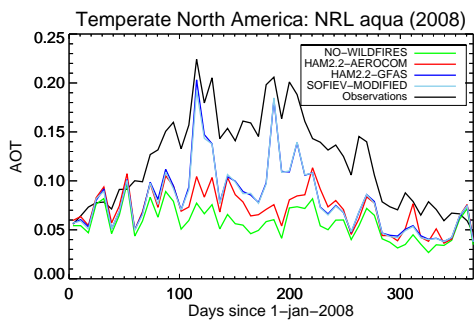

(f)

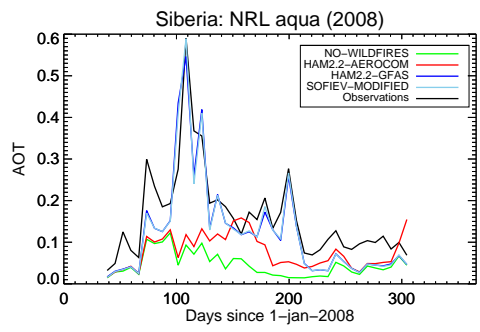

(i)

Figure 6. Temporal evolution of regional AOT for standard HAM2.2 plume heights based on GFAS emissions (HAM2.2-GFAS) as well as AEROCOM emissions (HAM2.2-AEROCOM) and a modified plume height parametrization of Sofiev et al. (2012) including a diurnal cycle of fire emissions and fire intensity (simulation SOFIEV-MODIFIED). The NO-WILDFIRES scenario is shown to distinguish wildfire-related biases from others. Observations are MODIS Aqua satellite measurements of AOT. All model data were collocated with the observations prior to averaging.

sake of clarity, the other SOFIEV simulations, which have been shown to only marginally influence parameters such as $\mathrm{BC}$ burden and concentrations, are not included. Likewise, the scenarios SOFIEV-2X-EMISSIONS-FRP, SURFACE and FT are excluded from this analysis as these simulations do not represent realistic states of present-day emission heights as well as emission inventories (Table 1). Thus, these simulations cannot be expected to match observations. The NO-WILDFIRES scenario is used to identify regions and time periods in which wildfires significantly contribute to the overall model bias.

\subsection{AERONET, MAN and MODIS}

ECHAM6-HAM2 computes AOT at $550 \mathrm{~nm}$ for clear-sky conditions. The model calculates a separate relative humidity $(\mathrm{RH})$ for the clear $(\mathrm{RH}<100 \%)$ and cloudy $(\mathrm{RH}=100 \%)$ parts of a grid box based on the grid box mean-specific humidity and the cloud fraction (see Stier et al., 2005, Sect. 2.6). The modeled AOT has global coverage and can be evaluated by comparison to observational AOT values which always refer to clear-sky conditions. Figures 5 and 6 provide a comparison of simulated and regionally averaged AOT to MODIS Aqua observations for the years 2006, 2007 and 2008. Time periods for which the NO-WILDFIRES values show little differences to all other simulations (e.g., Fig. 6, Boreal North America 2006, days 50-100 and Siberia 2008, days 250-300) indicate that the model bias in these periods has primarily to be attributed to non-wildfire sources. Generally those simulations based on GFAS emissions (HAM2.2GFAS and SOFIEV-MODIFIED) perform better than the HAM2.2-AEROCOM simulation. Note here that AERO$\mathrm{COM}$ emissions represent a monthly climatology and are as such not expected to match the observations for specific time periods. Therefore, the HAM2.2-AEROCOM simulation should be seen as a crude approximation which only 


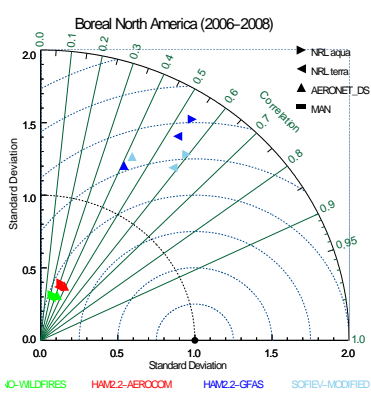

(a)
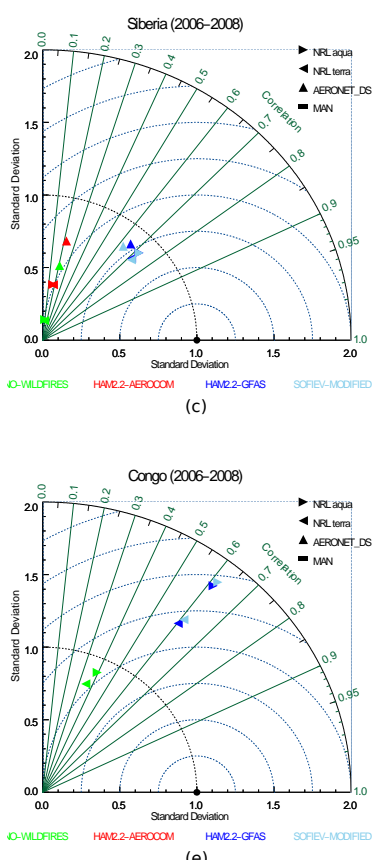
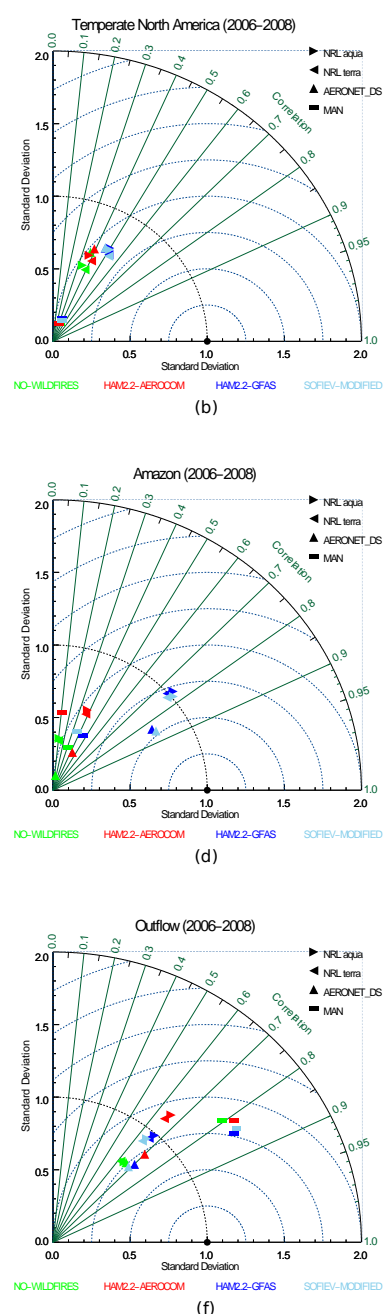

Figure 7. Taylor diagrams for comparison of simulations HAM2.2AEROCOM, HAM2.2-GFAS and SOFIEV-MODIFIED to satellite observations (MODIS NRL Aqua, MODIS NRL Terra) and groundbased observations (AERONET_DS, MAN), see text for more detailed description of simulation setups and observational data sets. The NO-WILDFIRES scenario excludes all wildfire emissions. Note that for region Congo (e) simulation HAM2.2-AEROCOM is not shown, because the standard deviations exceed the scale range.

represents the basic seasonal and regional emission patterns. Due to the distinct differences in plume heights between HAM2.2-GFAS and SOFIEV-MODIFIED and subsequent changes in aerosol lifetime (see Table 2), larger AOT values can be observed for HAM2.2-GFAS, especially during the local burning season. In Siberia and boreal North America, the model performance is highly variable from year to year. While massive burning events in 2008 are captured very well by HAM2.2-GFAS and SOFIEV-MODIFIED simulations, large biases are observable for the weak burning periods in boreal North America 2006 and Siberia 2007 with negligible differences in performance between the two simulations. By implementation of the modified plume height parametriza-

tion (SOFIEV-MODIFIED), the overestimation in AOT observable for HAM2.2-GFAS over the Amazon region during 2007 can be slightly reduced for the major biomass burning season. In the western Atlantic outflow region of the central African biomass burning plumes, the model is generally less capable of capturing the magnitude and seasonality of AOT variations.

Figure 7 provides Taylor plots which illustrate the model performance with regard to correlations and SD. The results show that the application of the fixed emission climatology AEROCOM is hardly able to improve the model performance compared to the NO-WILDFIRES scenario. Model runs with the GFAS emission inventory reach reasonable correlations of 0.4-0.85 depending on region and observational data set. The application of the Sofiev parametrization (SOFIEV-MODIFIED) instead of prescribed emission heights in HAM2.2-GFAS provides a moderate, but significant increase in correlation in boreal North America, Siberia and the Amazon. In the central African outflow region the biases of SD and correlation slightly increase, whereas there is no significant changes observable for temperate North America and the Congo region.

\subsection{CALIOP}

Figure 8 presents multi-year monthly AOT profiles (relative vertical AOT distribution) of ECHAM6-HAM2 simulations vs. CALIOP observations for the six major biomass burning regions specified in Fig. 1. For reasons of clarity, we limit our investigations to relative vertical AOT profiles and focus on the differences in AOT vertical profiles for prescribed (HAM2.2-GFAS and SURFACE) versus parametrized wildfire emission heights (SOFIEV-MODIFIED). In Veira et al. (2015) it has been shown that HAM2.2-GFAS overestimates plume heights by $1-2 \mathrm{~km}$ on average, while SOFIEVMODIFIED offers the best plume height performance. Note that the lowest $1.5 \mathrm{~km}$ of all CALIOP profiles are known to include particularly high uncertainties which also impact the higher layers. Nevertheless, Fig. 8 shows that the vertical AOT patterns of CALIOP and the model simulations SOFIEV-MODIFIED, HAM2.2-GFAS and SURFACE show general agreement for boreal and temperate North America and Central Africa (Congo).

There is a tendency of the model to simulate higher AOT values in the extratropical FT than CALIOP (boreal North America, Siberia), but this feature is not necessarily related to shortcomings in the model, but could also be related to known underestimation of AOT for low AOT values in the CALIOP data set. Remarkably, the impact of the emission height implementation (HAM2.2-GFAS vs. SOFIEVMODIFIED or SURFACE) is significantly smaller than the inter-annual variability and the differences between the model and CALIOP observations.

As biomass burning is seasonally varying, we further separate the analysis seasonally. Figure 9 provides correlation 

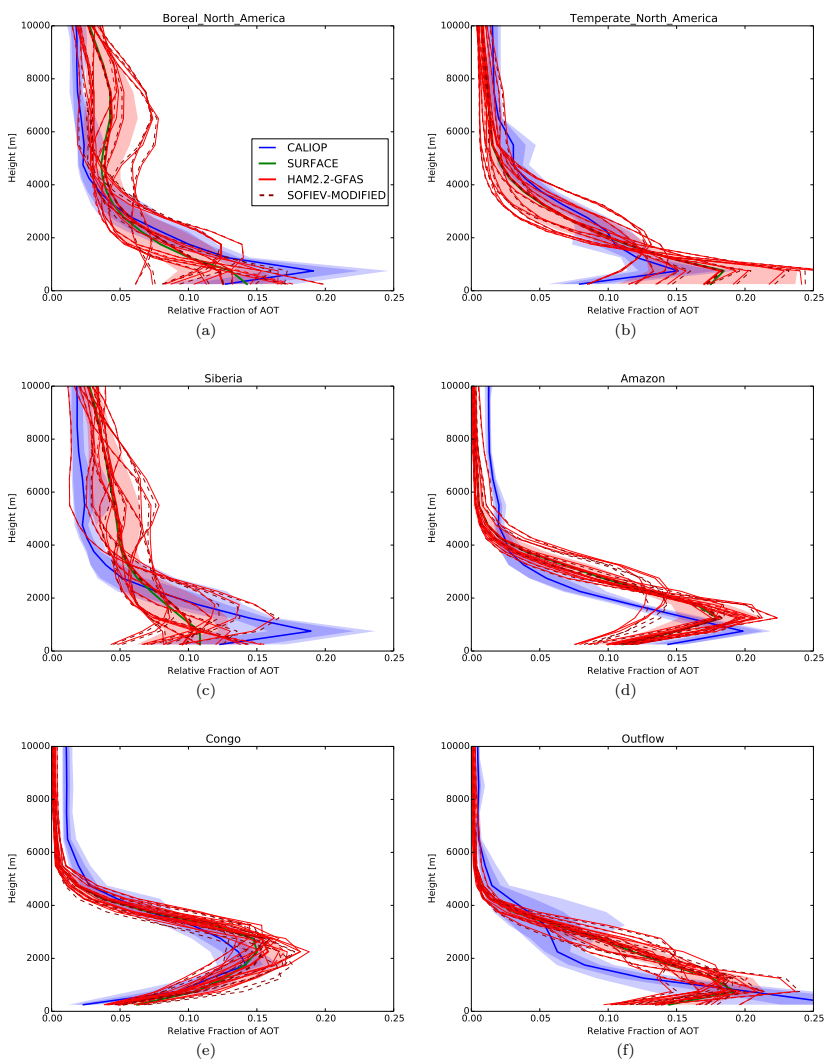

Figure 8. Regional AOT profiles averaged for 2006-2011 for CALIOP observations (solid blue line), simulation HAM2.2-GFAS (bold solid red line), simulation SOFIEV-MODIFIED (bold dashed dark red line) and simulation SURFACE (solid green line). Thin red lines indicate individual multi-year monthly means; red shading represents $1 \mathrm{SD}$ of monthly variations for model simulation HAM2.2-MODIFIED. Dark blue shading indicates $1 \mathrm{SD}$ of CALIOP monthly means; light blue shadings indicate minimum and maximum monthly means for CALIOP observations. All vertical lines represent relative AOT fractions at $532 \mathrm{~nm}$ (CALIOP) as well as at $550 \mathrm{~nm}$ (model simulations) of monthly averages for 20062011. Relative AOT fractions describe the integrated AOT of individual height layers $(500 \mathrm{~m}$ intervals for $0-5 \mathrm{~km}, 1 \mathrm{~km}$ intervals for $5-10 \mathrm{~km})$.

coefficients of spatially and temporally averaged relative AOT profiles for simulation SOFIEV-MODIFIED compared to CALIOP. For boreal North America and Siberia, a clear seasonal cycle in the model performance is observable with the highest correlations during the major wildfire season in these regions (June to August). Thus, the major shortcomings of the model in simulating vertical AOT profiles are not primarily related to wildfire emissions as such. Simulation HAM2.2-GFAS and simulation SURFACE show largely similar seasonal patterns in correlations (not shown). More realistic plume heights in simulation SOFIEV-MODIFIED compared to HAM2.2-GFAS increase the model performance in $65 \%$ of all cases, but the differences in correlation range only between 0.001 and 0.038 .

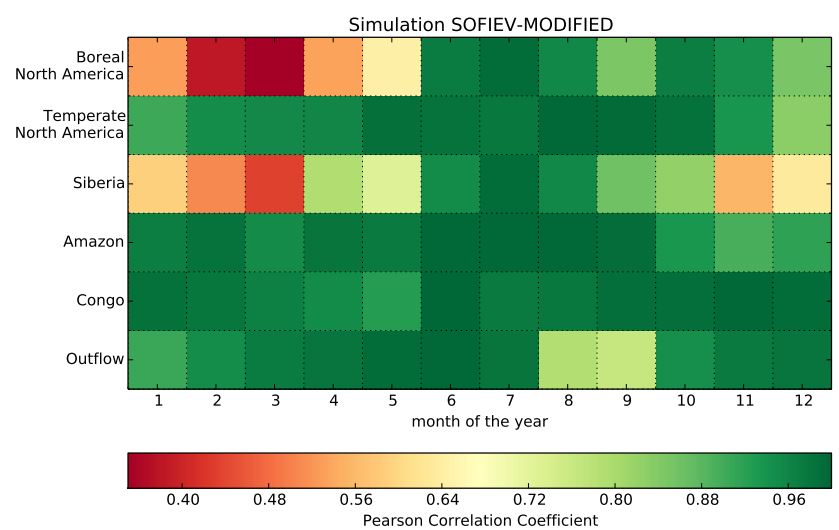

Figure 9. Pearson correlation coefficients of multi-year monthly means for CALIOP vs. SOFIEV-MODIFIED. Correlation coefficients greater than 0.48 are significant on a $95 \%$ confidence interval, while correlations smaller than 0.48 are not significant.

\subsection{Comparison to former studies}

Kipling et al. (2013) investigated the sensitivity of BC burdens and vertical profiles to emission heights in the ECHAM5-HAM2 and the HadGEM3-UKCA (Hadley Centre Global Environment Model version 3 - UK Chemistry and Aerosols) model. The authors found that differences in emission heights (PBL vs. prescribed 50-3000 m) did not significantly contribute to differences in the model performance. These findings are basically in line with our results which show that substantial differences in emission heights of $1-3 \mathrm{~km}$ entail differences of less than $10 \%$ in global BC burdens at least for scenarios which inject emissions neither very close to the surface nor only into the FT. On the other hand, our evaluation of different plume height parametrizations also indicates that the application of a semiempirical plume height parametrization which takes into account fire intensity as well as ambient meteorological conditions, marginally improves the overall model performance in AOT in the vicinity of the major biomass burning regions. Stein et al. (2009) also discovered a moderate improvement in model performance for the HYSPLIT (Hybrid Single Particle Lagrangian Integrated Trajectory) model by application of a simple, empirical plume height parametrization (Briggs, 1969). Koffi et al. (2012) provided a comprehensive comparison of CALIOP AOT profiles to different model simulations including ECHAM5-HAM1. The spread of the model ensemble presented in that study is considerably larger than the impact of different emission height parametrizations in our study. The general CALIOP uncertainties in AOT profiles (e.g., Kacenelenbogen et al., 2011; Ma et al., 2013) exceed by far the uncertainties in emission heights. A minor general importance of emission heights compared to the large uncertainties in the emission inventories has also been found by Gonzi et al. (2015) for CO emissions. 


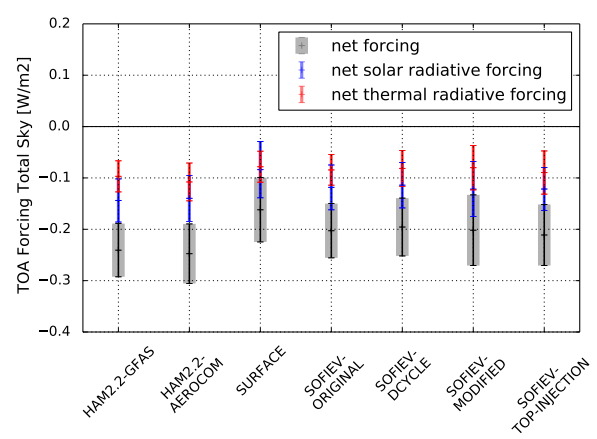

(a)

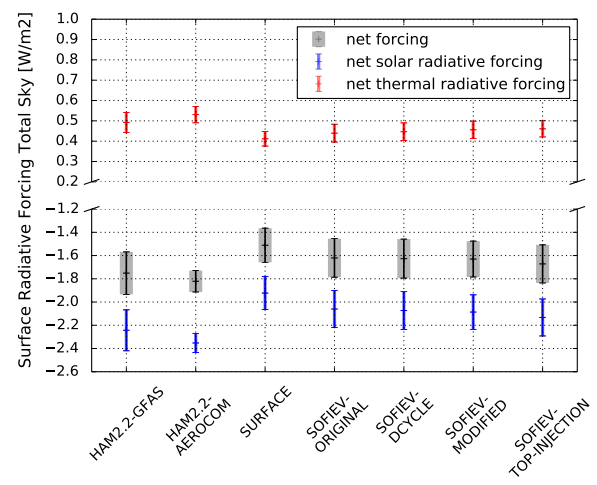

(c)

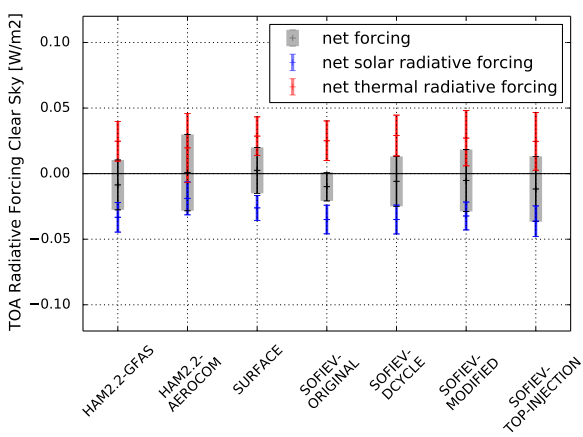

(b)

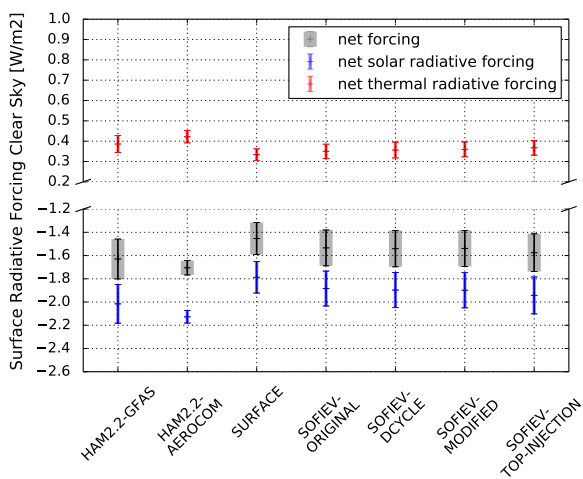

(d)

Figure 10. Simulated global mean net radiative forcing (RF) for top-of-atmosphere (TOA) total sky (a), TOA clear sky (b), surface total sky (c) and surface clear sky (d). The RF of all simulations refers to the NO-WILDFIRES scenario. Error bars indicate 1 SD of monthly mean RF values for 2005-2011. For a detailed description of the simulation setups, see Table 1.

\section{Radiative forcing}

The RF at the top of atmosphere (TOA) of wildfire emissions is analyzed to quantify the climate impact caused by different emission height representations. Here, the RF represents exclusively the radiative perturbation that is introduced by wildfire emissions $\left(\mathrm{BC}, \mathrm{OC}\right.$ and $\left.\mathrm{SO}_{2}\right)$, while anthropogenic emissions are kept constant. The radiative perturbation which is attributed to direct aerosol-radiation interference is referred to as clear sky RF; the RF which also includes indirect and semi-direct effects due to aerosol-cloud interaction is referred to as total sky RF. Aerosol-induced changes in atmospheric temperature profiles are implicitly included in both RF parameters, but due to our nudging towards reanalysis data every $6 \mathrm{~h}$, they are partly suppressed. Figure 10a and $\mathrm{b}$ visualize the total sky and clear-sky TOA RF for different plume height implementations. Global mean values for the total sky RF are also provided in Table 2.

The differences in TOA RF introduced by the differences between the SOFIEV simulations are negligible (total sky TOA RF ranges between $-0.196 \pm 0.056$ and $-0.211 \pm 0.060 \mathrm{~W} \mathrm{~m}^{-2}$ ). The most realistic implementation of emission heights (simulation SOFIEV-MODIFIED) leads to a TOA RF of $-0.20 \pm 0.07 \mathrm{~W} \mathrm{~m}^{-2}$ and is thus slightly less negative than the standard model HAM2.2-GFAS (total sky TOA RF of HAM2.2-GFAS: $-0.24 \pm 0.05 \mathrm{~W} \mathrm{~m}^{-2}$ ). The total sky TOA RF introduced by the extreme scenario of a SURFACE emission release is $-0.16 \pm 0.06 \mathrm{~W} \mathrm{~m}^{-2}$. Although the HAM2.2-GFAS simulation prescribes a certain emission injection into the FT for nearly all plumes, the difference in total sky TOA RF compared to the SURFACE simulation is only $0.08 \mathrm{~W} \mathrm{~m}^{-2}$.

The FT scenario entails a positive total sky TOA RF of $+0.66 \pm 0.24 \mathrm{~W} \mathrm{~m}^{-2}$ (not shown in Fig. 10). The change in the sign of the RF in the FT simulation can be attributed to the larger BC concentrations in the upper troposphere and lower stratosphere compared to the near-surface atmospheric levels. A doubling of FRP and emission fluxes in SOFIEV-2XEMISSIONS-FRP entails a TOA RF of $-0.36 \pm 0.11 \mathrm{~W} \mathrm{~m}^{-2}$ which is nearly a doubling in the negative RF compared to SOFIEV-ORIGINAL. When the AEROCOM wildfire emissions are used (HAM2.2-AEROCOM), the total sky TOA RF is $-0.25 \pm 0.06 \mathrm{~W} \mathrm{~m}^{-2}$ which is comparable to the HAM2.2GFAS simulation. Regionally, however, we find significant differences, that compensate on the global scale.

Figure $10 \mathrm{c}$ and d show the total respectively clear-sky surface RF for different plume height implementations. The surface RF of the simulation SOFIEV-ORIGINAL is $-1.62 \pm$ 

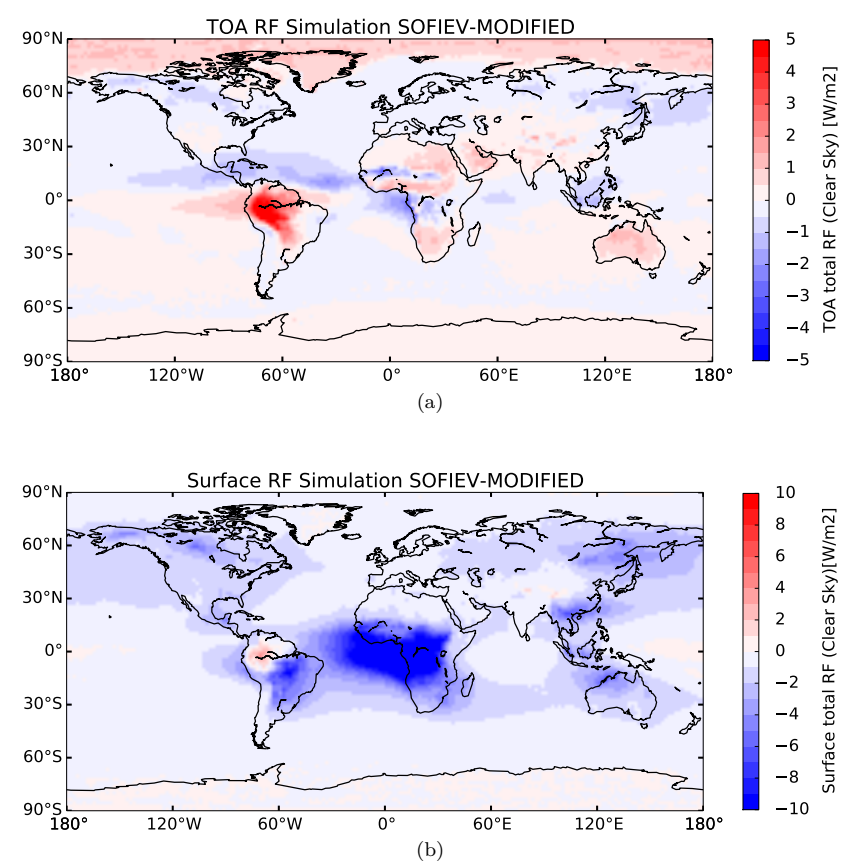

Figure 11. Clear-sky top-of-atmosphere radiative forcing (RF) (top plot) and clear-sky surface RF introduced by wildfire emissions (lower plot). Both figures show absolute differences of SOFIEVMODIFIED (applying the plume height parametrization which matches best to observations) and the NO-WILDFIRES scenario for which all wildfire emissions were turned off.

$0.17 \mathrm{~W} \mathrm{~m}^{-2}$ and ranges between the SURFACE and the HAM2.2-GFAS simulation (see Fig. 10c). Neither the implementation of a diurnal cycle in fire emissions (SOFIEVDCYCLE) nor a more realistic representation of deep plumes (SOFIEV-MODIFIED) alter the global surface RF by more then $\pm 0.05 \mathrm{~W} \mathrm{~m}^{-2}$. The same magnitude of changes in surface RF also applies for changes in the vertical distribution (SOFIEV-TOP-INJECTION). In contrast, the FT scenario causes a total sky surface RF of $-7.37 \pm 1.16 \mathrm{~W} \mathrm{~m}^{-2}$. A doubling in wildfire emissions and FRP would entail a total sky surface $\mathrm{RF}$ of $-3.28 \pm 0.34 \mathrm{~W} \mathrm{~m}^{-2}$ which represents roughly a doubling in surface RF compared to SOFIEV-DCYCLE $\left(-1.63 \pm 0.15 \mathrm{~W} \mathrm{~m}^{-2}\right)$ applying the same emission height parametrization (not shown). Similarly to the TOA RF, the impact of the choice of the emission inventory on the global surface RF (HAM2.2-AEROCOM: $1.82 \pm 0.09 \mathrm{~W} \mathrm{~m}^{-2}$ ) is small. The ratio of TOA to surface RF ranges from 0.11 to 0.14 for all simulations except for the FT scenario. These similar TOA to surface RF ratios indicate that the aerosolradiation interaction within the atmosphere shows a largely linear response to moderate changes in plume heights of up to a few kilometers. In contrast, for the extreme FT scenario this largely linear response does not apply, because the absorption of solar radiation by $\mathrm{BC}$ particles in the stratosphere is particularly important.
Although the global RF introduced by wildfire emissions is negative for all realistic simulations, regionally, positive and negative TOA RF values are observable which exceed the global values by up to 1 order of magnitude. Global maps of the total sky TOA and surface RF introduced by wildfire emissions for the SOFIEV-MODIFIED simulation, which represents the most realistic emission height scenario, are shown in Fig. 11a and b. Maximum TOA RF positive values of up to $+5 \mathrm{~W} \mathrm{~m}^{-2}$ are found over central South America, while a negative TOA RF is observable over most parts of the oceans. Although emission heights have a similar range in the Amazon region and central Africa, the TOA RF in Amazon is clearly positive while regions of positive and negative TOA RF are found in Africa. In contrast, the largest regional radiative effects at the surface are detectable in the vicinity of the African source regions, where the negative surface $\mathrm{RF}$ exceeds mean values of $-10 \mathrm{~W} \mathrm{~m}^{-2}$. Between scenarios SURFACE, SOFIEV-ORIGINAL, SOFIEV-DCYCLE, SOFIEV-MODIFIED and SOFIEV-TOP-INJECTION, maximum changes in surface RF introduced by changes in emission heights in the order of $1-3 \mathrm{~W} \mathrm{~m}^{-2}$ are limited to tropical Africa (not shown). In the extratropics, changes in surface RF rarely exceed $\pm 0.5 \mathrm{~W} \mathrm{~m}^{-2}$. In contrast, the switch from GFAS to AEROCOM emissions introduces a regional surface RF of $2-5 \mathrm{~W} \mathrm{~m}^{-2}$ in large parts of topical Africa, South America and also boreal North America.

Tosca et al. (2013) compared a simulation based on GFEDv3 wildfire emissions to a zero wildfire-emission control run to estimate the net change in surface shortwave fluxes in the community Earth system model (CESM). The authors only considered a prescribed wildfire emission release at the surface. The difference in net shortwave fluxes at the surface was found to be $-1.3 \pm 0.2 \mathrm{~W} \mathrm{~m}^{-2}$ leading to a surface cooling of $-0.13 \pm 0.01 \mathrm{~K}$. However, in contrast to our study, the sign of the TOA RF was positive $\left(+0.18 \pm 0.10 \mathrm{~W} \mathrm{~m}^{-2}\right)$.

A strong surface RF over tropical Africa is observable in both studies, but extratropical RF patterns show larger differences. For the Oslo-CTM2 (University of Oslo chemistrytransport model) model, simulations by Myhre et al. (2009) showed also a positive TOA RF value of $+0.07 \mathrm{~W} \mathrm{~m}^{-2}$. However, Jones et al. (2007) and Unger et al. (2010) found negative TOA RF values of $-0.29 \pm 0.07 \mathrm{~W} \mathrm{~m}^{-2}$ in the HadGEM1 model and $-0.25 \mathrm{Wm}^{-2}$ in the GISS (Goddard Institute for Space Studies) atmospheric compositionclimate model. TOA RF values simulated by our ECHAM6HAM2 simulations lie within the range of these references, but the spread between all our realistic simulations $(-0.16 \pm$ 0.06 to $-0.24 \pm 0.05 \mathrm{~W} \mathrm{~m}^{-2}$ ) is considerably smaller than the spread between the models. Presumably the differences in RF between the models are attributed to differences in transport mechanisms, removal processes and absorptivity of $\mathrm{BC}$ and $\mathrm{OC}$, not to the emission heights. 


\section{Summary and conclusions}

We investigated the impact of wildfire emission heights on atmospheric $\mathrm{BC}$ concentrations, deposition rates and radiation using the aerosol-climate modeling system ECHAM6HAM2. In addition to extreme scenarios of pure freetropospheric and pure near-surface emission release, we implemented different versions of a simple plume height parametrization and compared the introduced changes in aerosol concentrations and radiation to simulations with prescribed HAM2 standard plume heights. In addition, a hypothetical scenario of a climate-change-induced doubling in emissions and fire intensity provided a first estimate of the relative importance of changes in total emissions and emission heights. The impact of the emission height implementation of global emission height patterns and a global evaluation of the plume height parametrization is provided by the first part of this two-paper series (Veira et al., 2015). By comparison of our simulations to AOT observations from AERONET, MODIS and CALIOP we quantified the magnitude of improvements for climate modeling that can be expected from the implementation of a simple plume height parametrization. Based on the analysis of our results, we present the following findings:

- The atmospheric BC burden, total deposition rates and atmospheric radiation are more sensitive to emission inventories than to the details of the emission height implementation. The application of a diurnal cycle and a model-specific tuning of the plume height parametrization do not significantly change these results.

- Upper tropospheric and lower stratospheric BC concentrations are mainly determined by emission fluxes, tropical convection and the location of the emission release, while emission heights are of limited importance.

- Future changes in emission fluxes were found to be more important than changes in emission heights.

- Considerable changes in mean plume heights of 1.1$2.5 \mathrm{~km}$ alter the mean annual $\mathrm{BC}$ deposition rates over in the Arctic and Antarctica by 5-25\% for the unrealistic scenario of prescribed emission release at the surface. Thus, $\mathrm{BC}$ deposition rates on snow and subsequent changes in surface albedo show only a moderate sensitivity on wildfire emission heights.

- Our comparison of modeling results to AERONET, MAN and MODIS observations indicates that the ECHAM6-HAM2 model is capable of capturing the magnitude of the AOT variability as well as the seasonality in the vicinity of the major biomass burning regions. Mean correlations of $R^{2}=0.4-0.85$ between simulated and observed instantaneous AOT values can be achieved for major biomass burning regions with small improvements introduced by the plume height parametrization.

- The comparison of simulated, vertically resolved AOT to CALIOP observations shows that close to the major biomass burning regions, the implementation of the semi-empirical plume height parametrization marginally increases the model performance. Nevertheless, the CALIOP measurement uncertainties by far exceed the changes in AOT profiles caused by changes in wildfire emission heights.

- The top-of-atmosphere (TOA) radiative forcing (RF) of the wildfire emissions ranges between $-0.24 \pm$ $0.05 \mathrm{~W} \mathrm{~m}^{-2}$ for standard prescribed emission heights in ECHAM6-HAM2 $(25 \%$ of the emissions injected into the FT) and $-0.16 \pm 0.06 \mathrm{~W} \mathrm{~m}^{-2}$ for pure surface emission release. The application of a modified version of the Sofiev plume height parametrization, which offers the best match to observations, provides a TOA RF of $-0.20 \pm 0.07 \mathrm{~W} \mathrm{~m}^{-2}$ and thus shows little difference to the other plume height implementations. These changes in TOA RF are small compared to the spread of the overall wildfire emission RF in other state-of-the-art climate models $\left(-0.3\right.$ to $\left.+0.2 \mathrm{~W} \mathrm{~m}^{-2}\right)$.

Based on these findings, we suggest that for current stateof-the-art climate and Earth system models, simple plume height parametrization are sufficient means to study global aerosol climate interactions. More complex and advanced plume height models might be more appropriate tools for short-term regional studies of high resolution. Applying a correction factor of 3.4 to the GFAS wildfire emission inventory, fire emission heights turned out to be of limited importance compared to emission fluxes and removal processes. The assessment of the wildfire emission height impact on global $\mathrm{BC}$ concentrations, burden and deposition rates demonstrates that wildfire emission heights constitute only a second-order source of uncertainty. The known biases of global aerosol-climate models such as the improper representation of height-dependent aerosol-cloud interactions will persist even though emission heights are more appropriately represented.

Acknowledgements. We are grateful to the DFG for funding the Emmy-Noether junior research group "Fire in the Earth System". We also thank Angelika Heil and Samuel Remy (ECMWF, Reading, UK) for providing the GFASv1.1 data set and Stefan Kinne (MPI-M, Hamburg, Germany) for helpful comments on the model evaluation section. Moreover, we acknowledge the helpful and critical comments during the internal review process by Stephan Bakan. J. W. Kaiser was funded by the EU H2020 project MACC-III (contract no. 633080).

The article processing charges for this open-access publication were covered by the Max Planck Society. 
Edited by: K. Tsigaridis

\section{References}

Adames, A. F., Reynolds, M., Smirnov, A., Covert, D. S., and Ackerman, T. P.: Comparison of moderate resolution imaging spectroradiometer ocean aerosol retrievals with ship-based sun photometer measurements from the around the Americas expedition, J. Geophys. Res., 116, D16303, doi:10.1029/2010JD015440, 2011.

Andreae, M. and Merlet, P.: Emission of trace gases and aerosols from biomass burning, Global Biogeochem. Cy., 15, 955-966, doi:10.1029/2000GB001382, 2001.

Bond, T. C., Doherty, S. J., Fahey, D. W., Forster, P. M., Berntsen, T., DeAngelo, B. J., Flanner, M. G., Ghan, S., Kärcher, B., Koch, D., Kinne, S., Kondo, Y., Quinn, P. K., Sarofim, M. C., Schultz, M. G., Schulz, M., Venkataraman, C., Zhang, H., Zhang, S., Bellouin, N., Guttikunda, S. K., Hopke, P. K., Jacobson, M. Z., Kaiser, J. W., Klimont, Z., Lohmann, U., Schwarz, J. P., Shindell, D., Storelvmo, T., Warren, S. G., and Zender, C. S.: Bounding the role of Black Carbon in the climate system: a scientific assessment, J. Geophys. Res.Atmos., 118, 5380-5552, doi:10.1002/jgrd.50171, 2013.

Bourgeois, Q. and Bey, I.: Pollution transport efficiency toward the Arctic: Sensitivity to aerosol scavenging and source regions, J. Geophys. Res., 116, D08213, doi:10.1029/2010JD015096, 2011.

Bowman, D. M. J. S., Balch, J. K., Artaxo, P., Bond, W. J., Carlson, J. M., Cochrane, M. A., D'Antonio, C. M., Defries, R. S., Doyle, J. C., Harrison, S. P., Johnston, F. H., Keeley, J. E., Krawchuk, M. A., Kull, C. A., Marston, J. B., Moritz, M. A., Prentice, I. C., Roos, C. I., Scott, A. C., Swetnam, T. W., van der Werf, G. R., and Pyne, S. J.: Fire in the Earth system, Science, 324, 481-484, doi:10.1126/science.1163886, 2009.

Bréon, F.-M., Vermeulen, A., and Descloitres, J.: An evaluation of satellite aerosol products against sunphotometer measurements, Remote Sens. Environ., 115, 3102-3111, doi:10.1016/j.rse.2011.06.017, 2011.

Briggs, G.: Optimum formulas for buoyant plume rise, Philos. T. R. Soc. Lond., 265, 197-203, 1969.

Campbell, J. R., Reid, J. S., Westphal, D. L., Zhang, J., Tackett, J. L., Chew, B. N., Welton, E. J., Shimizu, A., Sugimoto, N., Aoki, K., and Winker, D. M.: Characterizing the vertical profile of aerosol particle extinction and linear depolarization over Southeast Asia and the Maritime Continent: the 2007-2009 view from CALIOP, Atmos. Res., 122, 520-543, doi:10.1016/j.atmosres.2012.05.007, 2013.

Chen, Y., Li, Q., Randerson, J. T., Lyons, E. A., Kahn, R. A., Nelson, D. L., and Diner, D. J.: The sensitivity of CO and aerosol transport to the temporal and vertical distribution of North American boreal fire emissions, Atmos. Chem. Phys., 9, 6559-6580, doi:10.5194/acp-9-6559-2009, 2009.

Colarco, P. R.: Transport of smoke from Canadian forest fires to the surface near Washington, D. C.: Injection height, entrainment, and optical properties, J. Geophys. Res., 109, D06203, doi:10.1029/2003JD004248, 2004.

Dee, D. P., Uppala, S. M., Simmons, A. J., Berrisford, P., Poli, P., Kobayashi, S., Andrae, U., Balmaseda, M. A., Balsamo, G.,
Bauer, P., Bechtold, P., Beljaars, A. C. M., van de Berg, L., Bidlot, J., Bormann, N., Delsol, C., Dragani, R., Fuentes, M., Geer, A. J., Haimberger, L., Healy, S. B., Hersbach, H., Hólm, E. V., Isaksen, L., Kå llberg, P., Köhler, M., Matricardi, M., McNally, A. P., Monge-Sanz, B. M., Morcrette, J.-J., Park, B.-K., Peubey, C., de Rosnay, P., Tavolato, C., Thépaut, J.N., and Vitart, F.: The ERA-Interim reanalysis: configuration and performance of the data assimilation system, Q. J. Roy. Meteorol. Soc., 137, 553-597, doi:10.1002/qj.828, 2011.

Dentener, F., Kinne, S., Bond, T., Boucher, O., Cofala, J., Generoso, S., Ginoux, P., Gong, S., Hoelzemann, J. J., Ito, A., Marelli, L., Penner, J. E., Putaud, J.-P., Textor, C., Schulz, M., van der Werf, G. R., and Wilson, J.: Emissions of primary aerosol and precursor gases in the years 2000 and 1750 prescribed data-sets for AeroCom, Atmos. Chem. Phys., 6, 4321-4344, doi:10.5194/acp-64321-2006, 2006.

Diner, D. J., Nelson, D. L., Chen, Y., Kahn, R. A., Logan, J., Leung, F.-Y., and Val Martin, M.: Quantitative studies of wildfire smoke injection heights with the Terra Multi-angle Imaging SpectroRadiometer, P. Soc. Photo.-Opt. Ins., 7089, 708908, doi:10.1117/12.795215, 2008.

Dumont, M., Brun, E., Picard, G., Michou, M., Libois, Q., Petit, J.R., Geyer, M., Morin, S., and Josse, B.: Contribution of lightabsorbing impurities in snow to Greenland's darkening since 2009, Nat. Geosci., 7, 509-512, doi:10.1038/ngeo2180, 2014.

Eck, T. F., Holben, B. N., Reid, J. S., Dubovik, O., Smirnov, A., Neill, N. T. O., Slutsker, I., and Kinne, S.: Wavelength dependence of optical depth of biomass burning, urban and desert dust aerosols, J. Geophys. Res., 104, 31333-31349, doi:10.1029/1999JD900923, 1999.

Freitas, S. R., Longo, K. M., Chatfield, R., Latham, D., Silva Dias, M. A. F., Andreae, M. O., Prins, E., Santos, J. C., Gielow, R., and Carvalho Jr., J. A.: Including the sub-grid scale plume rise of vegetation fires in low resolution atmospheric transport models, Atmos. Chem. Phys., 7, 3385-3398, doi:10.5194/acp-7-3385-2007, 2007.

Fromm, M., Lindsey, D. T., Servranckx, R., Yue, G., Trickl, T., Sica, R., Doucet, P., and Godin-Beekmann, S.: The untold story of pyrocumulonimbus, B. Am. Meteorol. Soc., 91, 1193-1209, doi:10.1175/2010BAMS3004.1, 2010.

Giorgetta, M. A., Jungclaus, J., Reick, C. H., Legutke, S., Bader, J., Böttinger, M., Brovkin, V., Crueger, T., Esch, M., Fieg, K., Glushak, K., Gayler, V., Haak, H., Hollweg, H.-D., Ilyina, T., Kinne, S., Kornblueh, L., Matei, D., Mauritsen, T., Mikolajewicz, U., Mueller, W., Notz, D., Pithan, F., Raddatz, T., Rast, S., Redler, R., Roeckner, E., Schmidt, H., Schnur, R., Segschneider, J., Six, K. D., Stockhause, M., Timmreck, C., Wegner, J., Widmann, H., Wieners, K.-H., Claussen, M., Marotzke, J., and Stevens, B.: Climate and carbon cycle changes from 1850 to 2100 in MPI-ESM simulations for the Coupled Model Intercomparison Project phase 5, J. Adv. Model. Earth Syst., 5, 572-597, doi:10.1002/jame.20038, 2013.

Gonzi, S., Palmer, P. I., Paugam, R., Wooster, M., and Deeter, M. N.: Quantifying pyroconvective injection heights using observations of fire energy: sensitivity of spaceborne observations of carbon monoxide, Atmos. Chem. Phys., 15, 4339-4355, doi:10.5194/acp-15-4339-2015, 2015. 
Goodrick, S., Achtemeier, G., and Larkin, N.: Modelling smoke transport from wildland fires: a review, Int. J. Wildland Fire, 22, 83-94, doi:10.1071/WF11116, 2012.

Haywood, J. and Boucher, O.: Estimates of the direct and indirect radiative forcing due to tropospheric aerosols: A review, Rev. Geophys., 38, 513-543, doi:10.1029/1999RG000078, 2000.

Holben, B. N., Eck, T. F., Slutsker, I., Tanre, D., Buis, J. P., Setzer, A., Vermote, E., Reagan, J. A., Kaufman, Y. J., Nakajima, T., Lavenu, F., Jankowiak, I., and Smirnov, A.: AERONET - a federated instrument network and data archive for aerosol characterization, Remote Sens. Environ., 66, 1-16, doi:10.1016/S00344257(98)00031-5, 1998.

Huijnen, V., Flemming, J., Kaiser, J. W., Inness, A., Leitão, J., Heil, A., Eskes, H. J., Schultz, M. G., Benedetti, A., Hadji-Lazaro, J., Dufour, G., and Eremenko, M.: Hindcast experiments of tropospheric composition during the summer 2010 fires over western Russia, Atmos. Chem. Phys., 12, 4341-4364, doi:10.5194/acp12-4341-2012, 2012.

Hyer, E. J., Reid, J. S., and Zhang, J.: An over-land aerosol optical depth data set for data assimilation by filtering, correction, and aggregation of MODIS Collection 5 optical depth retrievals, Atmos. Meas. Tech., 4, 379-408, doi:10.5194/amt-4-379-2011, 2011.

Ichoku, C., Kahn, R., and Chin, M.: Satellite contributions to the quantitative characterization of biomass burning for climate modeling, Atmos. Res., 111, 1-28, doi:10.1016/j.atmosres.2012.03.007, 2012.

Jian, Y. and Fu, T.-M.: Injection heights of springtime biomassburning plumes over peninsular Southeast Asia and their impacts on long-range pollutant transport, Atmos. Chem. Phys., 14, 3977-3989, doi:10.5194/acp-14-3977-2014, 2014.

Jones, A., Haywood, J. M., and Boucher, O.: Aerosol forcing, climate response and climate sensitivity in the Hadley Centre climate model, J. Geophys. Res.-Atmos., 112, D20211, doi:10.1029/2007JD008688, 2007.

Kacenelenbogen, M., Vaughan, M. A., Redemann, J., Hoff, R. M., Rogers, R. R., Ferrare, R. A., Russell, P. B., Hostetler, C. A., Hair, J. W., and Holben, B. N.: An accuracy assessment of the CALIOP/CALIPSO version 2/version 3 daytime aerosol extinction product based on a detailed multi-sensor, multi-platform case study, Atmos. Chem. Phys., 11, 3981-4000, doi:10.5194/acp-11-3981-2011, 2011

Kaiser, J. W., Heil, A., Andreae, M. O., Benedetti, A., Chubarova, N., Jones, L., Morcrette, J.-J., Razinger, M., Schultz, M. G., Suttie, M., and van der Werf, G. R.: Biomass burning emissions estimated with a global fire assimilation system based on observed fire radiative power, Biogeosciences, 9, 527-554, doi:10.5194/bg-9-527-2012, 2012.

Kinne, S., Schulz, M., Textor, C., Guibert, S., Balkanski, Y., Bauer, S. E., Berntsen, T., Berglen, T. F., Boucher, O., Chin, M., Collins, W., Dentener, F., Diehl, T., Easter, R., Feichter, J., Fillmore, D., Ghan, S., Ginoux, P., Gong, S., Grini, A., Hendricks, J., Herzog, M., Horowitz, L., Isaksen, I., Iversen, T., Kirkevåg, A., Kloster, S., Koch, D., Kristjansson, J. E., Krol, M., Lauer, A., Lamarque, J. F., Lesins, G., Liu, X., Lohmann, U., Montanaro, V., Myhre, G., Penner, J., Pitari, G., Reddy, S., Seland, O., Stier, P., Takemura, T., and Tie, X.: An AeroCom initial assessment - optical properties in aerosol component modules of global models, At- mos. Chem. Phys., 6, 1815-1834, doi:10.5194/acp-6-1815-2006, 2006.

Kipling, Z., Stier, P., Schwarz, J. P., Perring, A. E., Spackman, J. R., Mann, G. W., Johnson, C. E., and Telford, P. J.: Constraints on aerosol processes in climate models from vertically-resolved aircraft observations of black carbon, Atmos. Chem. Phys., 13, 5969-5986, doi:10.5194/acp-13-5969-2013, 2013.

Koch, D., Schulz, M., Kinne, S., McNaughton, C., Spackman, J. R., Balkanski, Y., Bauer, S., Berntsen, T., Bond, T. C., Boucher, O., Chin, M., Clarke, A., De Luca, N., Dentener, F., Diehl, T., Dubovik, O., Easter, R., Fahey, D. W., Feichter, J., Fillmore, D., Freitag, S., Ghan, S., Ginoux, P., Gong, S., Horowitz, L., Iversen, T., Kirkevåg, A., Klimont, Z., Kondo, Y., Krol, M., Liu, X., Miller, R., Montanaro, V., Moteki, N., Myhre, G., Penner, J. E., Perlwitz, J., Pitari, G., Reddy, S., Sahu, L., Sakamoto, H., Schuster, G., Schwarz, J. P., Seland, Ø., Stier, P., Takegawa, N., Takemura, T., Textor, C., van Aardenne, J. A., and Zhao, Y.: Evaluation of black carbon estimations in global aerosol models, Atmos. Chem. Phys., 9, 9001-9026, doi:10.5194/acp-9-9001-2009, 2009.

Koffi, B., Schulz, M., Bréon, F.-M., Griesfeller, J., Winker, D., Balkanski, Y., Bauer, S., Berntsen, T., Chin, M., Collins, W. D., Dentener, F., Diehl, T., Easter, R., Ghan, S., Ginoux, P., Gong, S., Horowitz, L. W., Iversen, T., Kirkevåg, A., Koch, D., Krol, M., Myhre, G., Stier, P., and Takemura, T.: Application of the CALIOP layer product to evaluate the vertical distribution of aerosols estimated by global models: AeroCom phase I results, J. Geophys. Res., 117, D10201, doi:10.1029/2011JD016858, 2012.

Liousse, C., Penner, J. E., Chuang, C., Walton, J. J., Eddleman, H., and Cachier, H.: A global three-dimensional model study of carbonaceous aerosols, J. Geophys. Res., 101, 19411-19432, doi:10.1029/95JD03426, 1996.

Lohmann, U. and Feichter, J.: Global indirect aerosol effects: a review, Atmos. Chem. Phys., 5, 715-737, doi:10.5194/acp-5-7152005, 2005.

Lohmann, U., Stier, P., Hoose, C., Ferrachat, S., Kloster, S., Roeckner, E., and Zhang, J.: Cloud microphysics and aerosol indirect effects in the global climate model ECHAM5-HAM, Atmos. Chem. Phys., 7, 3425-3446, doi:10.5194/acp-7-3425-2007, 2007.

Luderer, G., Trentmann, J., Winterrath, T., Textor, C., Herzog, M., Graf, H. F., and Andreae, M. O.: Modeling of biomass smoke injection into the lower stratosphere by a large forest fire (Part II): sensitivity studies, Atmos. Chem. Phys., 6, 5261-5277, doi:10.5194/acp-6-5261-2006, 2006.

Ma, X., Bartlett, K., Harmon, K., and Yu, F.: Comparison of AOD between CALIPSO and MODIS: significant differences over major dust and biomass burning regions, Atmos. Meas. Tech., 6, 2391-2401, doi:10.5194/amt-6-2391-2013, 2013.

Matichuk, R. I., Colarco, P. R., Smith, J. A., and Toon, O. B.: Modeling the transport and optical properties of smoke aerosols from African savanna fires during the Southern African Regional Science Initiative campaign (SAFARI 2000), J. Geophys. Res., 112, D08203, doi:10.1029/2006JD007528, 2007.

Myhre, G., Berglen, T. F., Johnsrud, M., Hoyle, C. R., Berntsen, T. K., Christopher, S. A., Fahey, D. W., Isaksen, I. S. A., Jones, T. A., Kahn, R. A., Loeb, N., Quinn, P., Remer, L., Schwarz, J. P., and Yttri, K. E.: Modelled radiative forcing of the direct aerosol 
effect with multi-observation evaluation, Atmos. Chem. Phys., 9, 1365-1392, doi:10.5194/acp-9-1365-2009, 2009.

Redemann, J., Vaughan, M. A., Zhang, Q., Shinozuka, Y., Russell, P. B., Livingston, J. M., Kacenelenbogen, M., and Remer, L. A.: The comparison of MODIS-Aqua (C5) and CALIOP (V2 \& V3) aerosol optical depth, Atmos. Chem. Phys., 12, 3025-3043, doi:10.5194/acp-12-3025-2012, 2012.

Reid, J. S., Koppmann, R., Eck, T. F., and Eleuterio, D. P.: A review of biomass burning emissions part II: intensive physical properties of biomass burning particles, Atmos. Chem. Phys., 5, 799825, doi:10.5194/acp-5-799-2005, 2005.

Remer, L., Kaufman, Y., Tanre, D., Mattoo, S., Chu, D., Martins, J., Li, R.-R., Ichoku, C., Levy, R., Kleidman, R., Eck, T., Vermote, E., and Holben, B.: The MODIS Aerosol Algorithm, Products, and Validation, J. Atmos. Sci., 62, 947-973, 2005.

Rio, C., Hourdin, F., and Chédin, A.: Numerical simulation of tropospheric injection of biomass burning products by pyro-thermal plumes, Atmos. Chem. Phys., 10, 3463-3478, doi:10.5194/acp10-3463-2010, 2010.

Samset, B. H., Myhre, G., Schulz, M., Balkanski, Y., Bauer, S., Berntsen, T. K., Bian, H., Bellouin, N., Diehl, T., Easter, R. C., Ghan, S. J., Iversen, T., Kinne, S., Kirkevåg, A., Lamarque, J.F., Lin, G., Liu, X., Penner, J. E., Seland, Ø., Skeie, R. B., Stier, P., Takemura, T., Tsigaridis, K., and Zhang, K.: Black carbon vertical profiles strongly affect its radiative forcing uncertainty, Atmos. Chem. Phys., 13, 2423-2434, doi:10.5194/acp-13-24232013, 2013.

Schmid, B., Michalsky, J., Halthore, R., Beauharnois, M., Harnson, L., Livingston, J., Russell, P., Holben, B., Eck, T., and Smirnov, A.: Comparison of aerosol optical depth from four solar radiometers during the fall 1997 ARM intensive observation period, Geophys. Res. Lett., 26, 2725-2728, doi:10.1029/1999GL900513, 1999.

Schutgens, N. A. J. and Stier, P.: A pathway analysis of global aerosol processes, Atmos. Chem. Phys., 14, 11657-11686, doi:10.5194/acp-14-11657-2014, 2014.

Schutgens, N. A. J., Nakata, M., and Nakajima, T.: Validation and empirical correction of MODIS AOT and AE over ocean, Atmos. Meas. Tech., 6, 2455-2475, doi:10.5194/amt-6-2455-2013, 2013.

Schwarz, J. P., Samset, B. H., Perring, A. E., Spackman, J. R., Gao, R. S., Stier, P., Schulz, M., Moore, F. L., Ray, E. A., and Fahey, D. W.: Global-scale seasonally resolved Black Carbon vertical profiles over the Pacific, Geophys. Res. Lett., 40, 5542-5547, doi:10.1002/2013GL057775, 2013.

Shi, Y., Zhang, J., Reid, J. S., Hyer, E. J., Eck, T. F., Holben, B. N., and Kahn, R. A.: A critical examination of spatial biases between MODIS and MISR aerosol products - application for potential AERONET deployment, Atmos. Meas. Tech., 4, 2823 2836, doi:10.5194/amt-4-2823-2011, 2011.

Smirnov, A., Holben, B. N., Giles, D. M., Slutsker, I., O’Neill, N. T., Eck, T. F., Macke, A., Croot, P., Courcoux, Y., Sakerin, S. M., Smyth, T. J., Zielinski, T., Zibordi, G., Goes, J. I., Harvey, M. J., Quinn, P. K., Nelson, N. B., Radionov, V. F., Duarte, C. M., Losno, R., Sciare, J., Voss, K. J., Kinne, S., Nalli, N. R., Joseph, E., Krishna Moorthy, K., Covert, D. S., Gulev, S. K., Milinevsky, G., Larouche, P., Belanger, S., Horne, E., Chin, M., Remer, L. A., Kahn, R. A., Reid, J. S., Schulz, M., Heald, C. L., Zhang, J., Lapina, K., Kleidman, R. G., Griesfeller, J., Gaitley, B. J., Tan,
Q., and Diehl, T. L.: Maritime aerosol network as a component of AERONET - first results and comparison with global aerosol models and satellite retrievals, Atmos. Meas. Tech., 4, 583-597, doi:10.5194/amt-4-583-2011, 2011.

Sofiev, M., Ermakova, T., and Vankevich, R.: Evaluation of the smoke-injection height from wild-land fires using remote-sensing data, Atmos. Chem. Phys., 12, 1995-2006, doi:10.5194/acp-12-1995-2012, 2012.

Spichtinger, N., Wenig, M., James, P., Wagner, T., Platt, U., and Stohl, A.: Satellite detection of a continental-scale plume of nitrogen oxides from boreal forest fires, Geophys. Res. Lett., 28, 4579-4582, doi:10.1029/2001GL013484, 2001.

Stein, A. F., Rolph, G. D., Draxler, R. R., Stunder, B., and Ruminski, M.: Verification of the NOAA Smoke Forecasting System: model sensitivity to the injection height, Weather Forecast., 24, 379-394, doi:10.1175/2008WAF2222166.1, 2009.

Stevens, B., Giorgetta, M., Esch, M., Mauritsen, T., Crueger, T., Rast, S., Salzmann, M., Schmidt, H., Bader, J., Block, K., Brokopf, R., Fast, I., Kinne, S., Kornblueh, L., Lohmann, U., Pincus, R., Reichler, T., and Roeckner, E.: Atmospheric component of the MPI-M Earth System Model: ECHAM6, J. Adv. Model. Earth Syst., 5, 146-172, doi:10.1002/jame.20015, 2013.

Stier, P., Feichter, J., Kinne, S., Kloster, S., Vignati, E., Wilson, J., Ganzeveld, L., Tegen, I., Werner, M., Balkanski, Y., Schulz, M., Boucher, O., Minikin, A., and Petzold, A.: The aerosol-climate model ECHAM5-HAM, Atmos. Chem. Phys., 5, 1125-1156, doi:10.5194/acp-5-1125-2005, 2005.

Tanre, D., Kaufman, Y. J., Herman, M., and Mattoo, S.: Remote sensing of aerosol properties over ocean using the MODIS/EOS spectral radiances, J. Geophys. Res., 102, 1697116988, doi:10.1029/96JD03437, 1997.

Textor, C., Schulz, M., Guibert, S., Kinne, S., Balkanski, Y., Bauer, S., Berntsen, T., Berglen, T., Boucher, O., Chin, M., Dentener, F., Diehl, T., Easter, R., Feichter, H., Fillmore, D., Ghan, S., Ginoux, P., Gong, S., Grini, A., Hendricks, J., Horowitz, L., Huang, P., Isaksen, I., Iversen, I., Kloster, S., Koch, D., Kirkevåg, A., Kristjansson, J. E., Krol, M., Lauer, A., Lamarque, J. F., Liu, X., Montanaro, V., Myhre, G., Penner, J., Pitari, G., Reddy, S., Seland, Ø., Stier, P., Takemura, T., and Tie, X.: Analysis and quantification of the diversities of aerosol life cycles within AeroCom, Atmos. Chem. Phys., 6, 1777-1813, doi:10.5194/acp-6-1777-2006, 2006.

Tosca, M. G., Randerson, J. T., and Zender, C. S.: Global impact of smoke aerosols from landscape fires on climate and the Hadley circulation, Atmos. Chem. Phys., 13, 5227-5241, doi:10.5194/acp-13-5227-2013, 2013.

Unger, N., Bond, T. C., Wang, J. S., Koch, D. M., Menon, S., Shindell, D. T., and Bauer, S.: Attribution of climate forcing to economic sectors, P. Natl. Acad. Sci. USA, 107, 3382-3387, doi:10.1073/pnas.0906548107, 2010.

Val Martin, M., Logan, J. A., Kahn, R. A., Leung, F.-Y., Nelson, D. L., and Diner, D. J.: Smoke injection heights from fires in North America: analysis of 5 years of satellite observations, Atmos. Chem. Phys., 10, 1491-1510, doi:10.5194/acp-10-14912010, 2010.

Val Martin, M., Kahn, R. A., Logan, J. A., Paugam, R., Wooster, M., and Ichoku, C.: Space-based observational constraints for 1-D fire smoke plume-rise models, J. Geophys. Res., 117, D22204, doi:10.1029/2012JD018370, 2012. 
Veira, A., Kloster, S., Wilkenskjeld, S., and Remy, S.: Fire emission heights in the climate system - Part 1: Global plume height patterns simulated by ECHAM6-HAM2, Atmos. Chem. Phys., 15, Atmos. Chem. Phys., 15, 7155-7171, doi:10.5194/acp-15-71552015, 2015.

von Hardenberg, J., Vozella, L., Tomasi, C., Vitale, V., Lupi, A., Mazzola, M., van Noije, T. P. C., Strunk, A., and Provenzale, A.: Aerosol optical depth over the Arctic: a comparison of ECHAMHAM and TM5 with ground-based, satellite and reanalysis data, Atmos. Chem. Phys., 12, 6953-6967, doi:10.5194/acp-12-69532012, 2012.

Wang, J., Christopher, S. A., Nair, U. S., Reid, J. S., Prins, E. M., Szykman, J., and Hand, J. L.: Mesoscale modeling of Central American smoke transport to the United States: 1. "Top-down" assessment of emission strength and diurnal variation impacts, J. Geophys. Res., 111, 1-21, doi:10.1029/2005JD006416, 2006.

van der Werf, G. R., Randerson, J. T., Giglio, L., Collatz, G. J., Kasibhatla, P. S., and Arellano Jr., A. F.: Interannual variability in global biomass burning emissions from 1997 to 2004, Atmos. Chem. Phys., 6, 3423-3441, doi:10.5194/acp-6-3423-2006, 2006.

Winker, D. M., Pelon, J., Coakley, J. A., Ackerman, S. A., Charlson, R. J., Colarco, P. R., Flamant, P., Fu, Q., Hoff, R. M., Kittaka, C., Kubar, T. L., Le Treut, H., McCormick, M. P., Mégie, G., Poole, L., Powell, K., Trepte, C., Vaughan, M. A., and Wielicki, B. A.: The CALIPSO mission: a global 3D view of aerosols and clouds, B. Am. Meteorol. Soc., 91, 1211-1229, doi:10.1175/2010BAMS3009.1, 2010.
Winker, D. M., Tackett, J. L., Getzewich, B. J., Liu, Z., Vaughan, M. A., and Rogers, R. R.: The global 3-D distribution of tropospheric aerosols as characterized by CALIOP, Atmos. Chem. Phys., 13, 3345-3361, doi:10.5194/acp-13-3345-2013, 2013.

Wotawa, G. and Trainer, M.: The influence of Canadian forest fires on pollutant concentrations in the United States, Science, 288, 324-328, doi:10.1126/science.288.5464.324, 2000.

Zhang, F., Wang, J., Ichoku, C., Hyer, E. J., Yang, Z., Ge, C., Su, S., Zhang, X., Kondragunta, S., Kaiser, J. W., Wiedinmyer, C., and da Silva, A.: Sensitivity of mesoscale modeling of smoke direct radiative effect to the emission inventory: a case study in northern sub-Saharan African region, Environ. Res. Lett., 9, 075002, doi:10.1088/1748-9326/9/7/075002, 2014.

Zhang, K., O’Donnell, D., Kazil, J., Stier, P., Kinne, S., Lohmann, U., Ferrachat, S., Croft, B., Quaas, J., Wan, H., Rast, S., and Feichter, J.: The global aerosol-climate model ECHAM-HAM, version 2: sensitivity to improvements in process representations, Atmos. Chem. Phys., 12, 8911-8949, doi:10.5194/acp-12-89112012, 2012. 